\title{
Climate Change Impact, Adaptation, and Mitigation in Temperate Grazing Systems: A Review
}

\author{
Afshin Ghahramani ${ }^{1, *}$, S. Mark Howden ${ }^{2}{ }^{\mathbb{D}}$, Agustin del Prado ${ }^{3}$, Dean T. Thomas ${ }^{4}$, \\ Andrew D. Moore ${ }^{5}$, Boyu Ji ${ }^{6}$ and Serkan Ates ${ }^{7}$ \\ 1 Centre for Sustainable Agricultural Systems, Institute for Life Science and the Environment, University of \\ Southern Queensland, Toowoomba, QLD 4350, Australia \\ 2 Climate Change Institute, The Australian National University, Canberra, ACT 2601, Australia; \\ mark.howden@anu.edu.au \\ 3 Basque Centre for Climate Change (BC3), Edificio Sede $N^{\circ}$ 1, Planta 1, Parque Científicode UPV/EHU, \\ Barrio Sarriena s/n, 48940 Leioa, Spain; agustin.delprado@bc3research.org \\ 4 CSIRO Agriculture and Food, Floreat, WA 6014, Australia; dean.thomas@csiro.au \\ 5 CSIRO Agriculture and Food, Canberra, ACT 2601, Australia; Andrew.Moore@csiro.au \\ 6 Centre for Compassionate Conservation, Faculty of Science, University of Technology Sydney, Ultimo, \\ NSW 2007, Australia; Boyu.Ji@uts.edu.au \\ 7 Department of Animal and Rangeland Sciences, Oregon State University, Corvallis, OR 97331, USA; \\ serkan.ates@oregonstate.edu \\ * Correspondence: afshin.ghahramani@usq.edu.au; Tel.: +61-7-4631-1178
}

Received: 26 November 2019; Accepted: 10 December 2019; Published: 16 December 2019

check for updates

\begin{abstract}
Managed temperate grasslands occupy $25 \%$ of the world, which is $70 \%$ of global agricultural land. These lands are an important source of food for the global population. This review paper examines the impacts of climate change on managed temperate grasslands and grassland-based livestock and effectiveness of adaptation and mitigation options and their interactions. The paper clarifies that moderately elevated atmospheric $\mathrm{CO}_{2}\left(\mathrm{eCO}_{2}\right)$ enhances photosynthesis, however it may be restiricted by variations in rainfall and temperature, shifts in plant's growing seasons, and nutrient availability. Different responses of plant functional types and their photosynthetic pathways to the combined effects of climatic change may result in compositional changes in plant communities, while more research is required to clarify the specific responses. We have also considered how other interacting factors, such as a progressive nitrogen limitation (PNL) of soils under $\mathrm{eCO}_{2}$, may affect interactions of the animal and the environment and the associated production. In addition to observed and modelled declines in grasslands productivity, changes in forage quality are expected. The health and productivity of grassland-based livestock are expected to decline through direct and indirect effects from climate change. Livestock enterprises are also significant cause of increased global greenhouse gas (GHG) emissions (about 14.5\%), so climate risk-management is partly to develop and apply effective mitigation measures. Overall, our finding indicates complex impact that will vary by region, with more negative than positive impacts. This means that both wins and losses for grassland managers can be expected in different circumstances, thus the analysis of climate change impact required with potential adaptations and mitigation strategies to be developed at local and regional levels.
\end{abstract}

Keywords: grassland; livestock; climate change; adaptation; mitigation; grazing system; ecosystem health; food security 


\section{Introduction}

Globally, managed temperate grasslands account for $25 \%$ of the land area that is $70 \%$ of the world's agricultural land [1]. This land use supplies 50\% of the global livestock intake [2], which is the source of $15 \%$ of the energy and $25 \%$ of the protein consumed by the global human population [3]. However, domesticated livestock systems are a significant component of the global anthropogenic greenhouse gas (GHG) emissions budget [4]. Increases in global GHG emissions are already likely to be affecting global temperatures [5], the global water cycle [6] and other climate elements, e.g., vapour pressure deficit. These changes are predicted to result in reductions in agricultural productivity in many regions but to increases in a small number of region [7]. Further changes in the global climate, with associated increases in the return period, size, and duration of extreme high temperature events and following heat stresses are predicted for the 21st century, along with changes in rainfall and rainfall extremes [5]. The climate change impacts and adaptation on pasture-based temperate livestock systems have been given relatively little attention in comparison to crop production despite the importance of grasslands and livestock for global food security and as a major global land use [8,9]. Part of the reason may be that the inference of climate change for managed grassland systems are complex, with many interacting effects. For example, while the projected temperature and rainfall conditions anticipated to reduce production of both plant and animal in places such as Australia [10] and Mediterranean regions [11,12], elevated atmospheric carbon dioxide $\left(\mathrm{eCO}_{2}\right)$ concentrations have a range of largely positive effects on plant function [13,14]. This includes a reduction in sensitivities to lower rainfall and in plant mortality and an increase in plant recovery during severe water stress events [15]. Overall, $\mathrm{eCO}_{2}$ can reduce the plant protein concentration in $\mathrm{C} 3$ grasses, reducing forage quality [16]. In addition, positive effects of $\mathrm{eCO}_{2}$ can be offset with associated changes, e.g., a decline in available soil nutrients [17]. The balance between these different components is challenging to evaluate as grazing systems are diverse, with varied management goals and strategies, and future climate projections have a high level of uncertainty. Hence, a dynamic and regionally focused risk management approach to climate change adaptation will be needed.

Livestock systems are also significant contributors (about 12-19\%) to the global greenhouse gas emissions budget [18]. This occurs through emissions of enteric methane (44\% of the sectoral emissions), nitrous oxide $\left(\mathrm{N}_{2} \mathrm{O}\right)\left(29 \%\right.$ from excreta and feed-crops), and $\mathrm{CO}_{2}(27 \%)$ via land clearing, soil carbon (C) loss and fossil fuel use [4,19]. Through a range of management options (e.g., allocating greater areas to permanent species, decreasing stocking rates and silvopastoralism), livestock systems can also sequester carbon in soil C pools [20,21]. The majority of livestock emissions are from ruminants (80\%) with the remainder from monogastric livestock such as pigs and chickens [19]. The current trend of increased livestock numbers and consumption of livestock products globally is anticipated to continue [22], thereby emphasising the importance of developing effective emission-reduction options from this sector. Importantly, some of these options could benefit from being synergistic [23] with the use of climate adaptation strategies (e.g., replacing grassland monocultures by mixed legume-grass swards) [24].

The Intergovernmental Panel on Climate Change [7] defines climate adaptation as: "The process of adjustment to actual or expected climate and its effects. In human systems, adaptation seeks to moderate harm or exploit beneficial opportunities. In natural systems, human intervention may facilitate adjustment to expected climate and its effects". Following the IPCC definition, in this review, we define climate adaptation to be any strategy to avoid or compensate for, or take advantage of, changes in climate that can adversely affect the production and profitability of grazing systems.

This review paper will examine the impacts of atmospheric and climate change on managed temperate grasslands and grassland-based animals (sheep and cattle), exploring the potential effectiveness of adaptation approaches and mitigation options and their interactions, along with their environmental consequences. This paper does not cover intensively-housed ruminant production. The scope of the review has been confined to the grassland-based extensive livestock industry, due to its reliance on rain-fed feed production from native and introduced forage plants and the limited options to manage the animals' environment compared with intensive animal industries such as dairy production (i.e., there is less control of thermal conditions, importing additional feed and irrigating pastures). The extensive livestock 
businesses may include elements where animals are transitioned to systems that are more intensive e.g., feedlots for finishing, but this would usually be a relatively small part of the overall enterprise. However, issues addressed in this paper may also be relevant to less intensive dairy farming systems.

\section{Impacts of Climate Change on Grasslands}

\subsection{Observed Effects of e $\mathrm{CO}_{2}$ on Compositional Change and Different Functional Types}

The grasslands are expected to exhibit a more complex responses to climate change compared to the other agricultural systems such as cropping or forestry due to multiple interactions between animals and plants and within plant communities [25]. Furthermore, there are often considerable time lags between taking action and the resultant outcomes. Most studies have focused on responses of plant monocultures to $\mathrm{eCO}_{2}$ and to changes in temperature and rainfall, while many managed grasslands comprise multiple plants of different functional types [26]. Different functional types of plant species (e.g., $\mathrm{C} 3$ vs. C4 plants and legume vs. grasses) respond differently to elevated $\mathrm{CO}_{2}$, leading to changes in the composition of plant species in grassland [27]. These changes can significantly affect livestock production. Mixtures of species with $\mathrm{C}_{3}$ and $\mathrm{C}_{4}$ photosynthetic pathways are found in both subtropical and some temperate grasslands. The former should be favoured by $\mathrm{eCO}_{2}$ and the latter by increasing temperatures [28]. However, these responses of plant functional types may not be widespread across all temperate grasslands. Bolger et al. [29] reported that variability of plant's growth in response to $\mathrm{eCO}_{2}$ by species within the same functional type was much greater compared to the average variability between functional types. Morgan et al. [30] reported that reproductive responses to $\mathrm{eCO}_{2}$ were highly variable and unrelated to plants functional groups in Mediterranean and temperate grasslands, while in general the fertilisation effect of $\mathrm{eCO}_{2}$ on aboveground biomass was relatively greater in dry regions or years. Thus, changes in composition under $\mathrm{eCO}_{2}$ can be controlled by the specific species' responses (about which little is known) in the sward, and the prevailing local climate conditions.

\subsection{Observed Progressive Nitrogen Limitation (PNL)}

The interactions between plant animal and management add further complexities discussed in Section 2.1. The prediction of "progressive nitrogen limitation" (PNL) is an example. The sequestered nitrogen $(\mathrm{N})$ in grassland soil is observed to decline progressively under $\mathrm{eCO}_{2}$ [31], thus, lack of $\mathrm{N}$ available to plant can restrict plant responses to $\mathrm{eCO}_{2}[17,32]$.

Newton et al. $[33,34]$ have reported evidence for PNL in grasslands managed by cutting, but, it may be ameliorated in grazed grasslands by the production of excreta $\mathrm{N}$, which results in the localised return of nutrients to the soil [35] although this is prone to $\mathrm{N}$ losses (especially from urine). For example, soil $\mathrm{N}$ concentration has been shown to benefit from plant-animal interactions that may occur with higher grazing intensity [36]. Further, the variable nature of plant species' composition of grass/legume pastures under grazing can act to regulate the concentration of $\mathrm{N}$ in the ecosystem [37], and a similar ecological response to $\mathrm{eCO}_{2}$ might enable soil $\mathrm{N}$ levels to be maintained in grazed systems. A response in the plant population in N-limited soils will also be important to maintain animal productivity, as the $\mathrm{N}$ content of pasture grasses may be considerably below the requirement of ruminants throughout the year, compared with legumes [38]. The PNL can be avoided by the strategic use of $\mathrm{N}$ fertiliser, or by addressing other nutrient constraints [35], where enhanced fixation of $\mathrm{N}$ by legumes in response to $\mathrm{eCO}_{2}$ does not increase $\mathrm{N}$ inputs to the system. In fact, there is a range of reasonable mechanisms whereby $\mathrm{N}$-limitations may be overcome in grassland ecosystems under future climate scenarios [39].

\subsection{Observed Effect of e $\mathrm{CO}_{2}$ on Grassland Production and Quality}

The impacts of $\mathrm{eCO}_{2}$ on biophysical interactions of plants have been examined across the world in free air $\mathrm{CO}_{2}$ enrichment (FACE) experiments, but only a few of these addressed managed grasslands that are under grazing. The impacts of $\mathrm{eCO}_{2}$ on plant physical and chemical characteristics will alter not only the yield but also the nutritional quality of forage for livestock [40], which effect will vary 
widely by region. A review by Soussana and Lüscher) [25] reported that doubling of $\mathrm{CO}_{2}$ concentration increased the photosynthesis rate in range between $30 \%$ and $50 \%$ for $\mathrm{C}_{3}$ species. Campbell et al. [41] observed that doubling atmospheric $\mathrm{CO}_{2}$ concentrations could stimulate plant production by $17 \%$ in field experiments in USA, Australia, and Europe, while Tubiello et al. [13] concluded that observed increases in aboveground production of $\mathrm{C}_{3}$ pasture grasses and legumes from doubled $\mathrm{eCO}_{2}$ would be of the order of $+10 \%$ and $+20 \%$, respectively. However, it may be that the main increase in production with $\mathrm{eCO}_{2}$ occurs belowground not aboveground, as found by Newton et al. [33] in their study of a multi-species, grazed temperate pasture with cutting under $475 \mathrm{ppm} \mathrm{eCO}$. The experimental results reported by Newton et al. [33] demonstrate the levels of complexity in managed grasslands under $\mathrm{eCO}_{2}$, even without changes in rainfall and temperature or in the absence of animal interactions. They found that photosynthesis were stimulated with $\mathrm{eCO}_{2}$, but it was observed that roots had extra growth compared to shoots, demonstrating the complexity of understanding required to be clarified even when there is no changes in other climatic factors or animal interactions.

\subsection{Observed Effect of e $\mathrm{CO}_{2}$ on Legumes}

Legume species are observed to respond relatively better than grasses under $\mathrm{eCO}_{2}$ through increase in nitrogen fixation (e.g., [42]). In an experiment by Newton et al. [33], the legume content of sward increased under $\mathrm{eCO}_{2}$ (with species-specific interactions between defoliation and $\mathrm{eCO}_{2}$ ) which doubled biologically fixed N in the soil. Despite this greater N input, however, there was observed PNL in the soil that was confirmed in a later experiment by Newton et al. [34]. Overall, the PNL decreases protein content of grass species but forage quality of whole pasture can be compensated by a greater proportion of legumes that are rich in protein. When this experiment was extended, Newton et al. [43] found that in the longer term (after a further five years), the proportions of legumes, grasses, and forbs did not change under impact of the both ambient and elevated $\mathrm{CO}_{2}$ due to diet preferences [44] for legumes and forbs over grass. There was a greater variability under $\mathrm{eCO}_{2}$, which was related to stimulated growth rates of legumes and forbs exposed to defoliation, thus resulted in small difference in actual composition of the community [43].

\subsection{Observed Effects of eCO $\mathrm{CO}_{2}$ in Interaction with Temperature and Rainfall}

The field experiments observing the interactions between $\mathrm{eCO}_{2}$ and temperature and rainfall identify the complexity of a plant's response to $\mathrm{eCO}_{2}$ even further than the above sections presented in this paper because temperature and rainfall will also likely change as $\mathrm{CO}_{2}$ concentration increases. In an area of French grassland grazed at a low-intensity, negative impact simulated from increase in temperature and summer drought for 2080 exceeded positive impact of $\mathrm{eCO}_{2}$ and net primary productivity (NPP) decreased with changes in all three factors of temperature, rainfall, and $\mathrm{eCO}_{2}$ [45]. In this experiment, warming had a more significant impact than $\mathrm{eCO}_{2}$ in increasing the observed contribution of legumes to NPP. In another study under controlled environment conditions, Roy et al. [14] found that $\mathrm{eCO}_{2}\left(520 \mu \mathrm{mol} \cdot \mathrm{mol}^{-1}\right)$ not only offset the decline of ecosystem health (soil monoliths of intact soil and plant communities) and carbon uptake during the simulated extreme climatic events (drought and heat wave) but also helped its recovery after the extreme events. They attributed this effect to increases of root growth and plant $\mathrm{N}$ uptake.

In relation to PNL, a FACE experiment on an unfertilised grassland in Tasmania, Australia [46] reported PNL similar to the observations by Newton et al. [33] in an $\mathrm{eCO}_{2}$-only treatment in New Zealand, but there was no evidence of PNL when temperature was also increased by $2{ }^{\circ} \mathrm{C}$ Hovenden et al. [46] did not report a response of $\mathrm{NPP}$ to $\mathrm{eCO}_{2}$ or warming in this grassland. Later, Hovenden et al. [47] found that the effect of the $\mathrm{eCO}_{2}$ mainly depends upon seasonal rainfall, with high rainfall during cool seasons leading to PNL. 


\subsection{Modelled Impacts of Climate Change across the Globe}

The models have predicted different responses of NPP to changes in climate around the world, as summarised in Table 1. In addition to the modelling approach, the NPP responses can be related to the local conditions and the magnitude of projected changes in climate. Parton et al. [48] predicted an overall decrease in plant production, especially in global temperate steppes and cold rangelands, and little changes in humid tropics and cold desert steppe but with a potentially significant increase in NPP in mesic regions and dry savannas. According to Rounsevell et al. [49], it is unlikely that climate change of near future will have a negative impact on grasslands in England and Wales, while Riedo et al. [50] predicted a small positive effect on productivity of grasslands in the central Europe. More recently, there is a prediction [51] that NPP would increase across grasslands in Europe but with significant regional variability.

For grasslands in the United States, pasture production is generally predicted to increase under projected climate scenarios [52]. By using the IFSM model [53] at the farm level, Thivierge et al. (2016) [54] assessed the effect of future Canadian climate and $\mathrm{eCO}_{2}$ on alfalfa and timothy grown alone or in the mixture. They reported an increase in production and decline in forage quality with small changes in climate but yield declined under more severe climate change scenarios.

For a set of representative sites in mainland of southern Australia, reduction in grassland production predicted by Cullen et al. [55] whenever there was more than about $10 \%$ decrease in rainfall, but plant production in Tasmania was simulated to be robust even with a decline in rainfall of up to $20 \%$. This can be associated with the hydrological response of the soil (to factors such as topography, soil type) as well as local climate, e.g., vapour pressure deficit that can alter partitioning between evaporation and transpiration.

Moore and Ghahramani [10] simulated temperate grazing systems of Australia under the impact of climate change by 2050 and reported that the projected impact on production, depending on the global circulation model (GCM), would be in a range between $-18 \%$ decrease to $+6 \%$. This variability was caused by uncertainties in the projected rainfall for this mid-latitude region where plant growth tends to be water-limited. Projected changes in production were much greater in low rainfall zones where a significant decline was predicted. In arid West Asia and North Africa (WANA Region) grasslands, Belgacem and Louhaichi [56] investigated the effect of climate change on species spatial distributions of threatened range species through using climate envelope modelling. Their results indicated that the effects of climate change on distribution of shrubs are highly species dependant. For example, $S$. vermiculata had high vulnerability as evidenced by the projected decline in the areas of their distribution, while $H$. salicornicum and H. schmittianum species that are characterized with low palatability and wide ecological niches (can adapt and survive in wide range of soils, temperature, water requirements) had an advantage due to the reduced competition for water and nutrients.

In some warmer regions where pasture productivity is expected to decrease as a result of a decline in rainfall and higher temperatures, forage quality has been predicted to increase because plant $\mathrm{N}$ concentration is expected to increase [57]. However, the higher carbon: nitrogen ratios under $\mathrm{eCO}_{2}$ may reduce these effects and the overall outcome for the composition of the plant community will be important.

\subsection{Modelled Impact on Seasonal Duration of Grazing}

Phelan et al. [58] predicted that for most European countries there would be an increase in grazing season length under climate change with the greatest increase being up to 2.5 months in the north-east of Europe. In their study, spatial relationships between bioclimatic variables and observed grazing season length were extrapolated to future climate change scenarios. This indicated increased variability between regions and decreases in grazing season length of about 1.5 months in the west coast of Britain, west of France, and the south-west of Norway. Surprisingly, they found that bioclimatic variables associated with high temperatures or dry conditions were not closely related to grazing season length. 
Table 1. Modelled impacts of climate changes on grassland.

\begin{tabular}{|c|c|c|c|c|c|c|}
\hline Reference & Model Name & Region & $\begin{array}{l}\mathrm{eCO}_{2} \\
(\mathrm{ppm})\end{array}$ & $\begin{array}{l}\text { Temperature } \\
\text { Increase } \\
\left({ }^{\circ} \mathrm{C}\right)\end{array}$ & $\begin{array}{l}\text { Projected } \\
\text { Future }\end{array}$ & Modelled Impact \\
\hline Parton et al. [48] & CENTURY & $\begin{array}{l}\text { Cold desert steppe, temperate steppe, } \\
\text { humid temperate, Mediterranean, dry } \\
\text { savanna, humid savanna }\end{array}$ & 700 & $2-5$ & $\begin{array}{l}\text { Next } 200 \\
\text { years }\end{array}$ & $\begin{array}{l}\text { - } \quad \text { Overall decrease in plant production; } \\
\text { - } \quad \text { Little net change in humid tropic and cold desert steppe; } \\
\text { mesic regions. }\end{array}$ \\
\hline $\begin{array}{c}\text { Rounsevell et al. } \\
\text { [49] }\end{array}$ & $\begin{array}{c}\text { Grassland suitability } \\
\text { model }\end{array}$ & $\begin{array}{l}\text { England and Wales } \\
\text { (Europe) }\end{array}$ & NA & 2 & $\begin{array}{l}\text { Next } 30 \\
\text { years }\end{array}$ & $\begin{array}{l}\text { - } \quad \text { Overall negative impact on grasslands; } \\
\text { - } \quad \text { Resilient grassland production with }+2 \mathrm{oC} \text { temperature and } \\
\quad \pm 10 \% \text { precipitation; } \\
\text { - } \quad \text { Exacerbate drought stress of intensively manages grassland with }+4 \mathrm{oC} \text {. }\end{array}$ \\
\hline Riedo et al. [50] & $\begin{array}{l}\text { Dynamic ecosystem } \\
\text { model }\end{array}$ & $\begin{array}{l}\text { Payerne and La Chaux-de-Fonds } \\
\text { (Europe) }\end{array}$ & 660 & $2.6-2.8$ & $\begin{array}{c}14 \\
\text { growing } \\
\text { seasons }\end{array}$ & 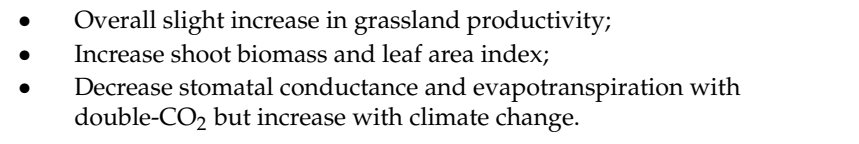 \\
\hline Morales et al. [51] & LPH-GUESS & Europe & $556-718$ & $4.5-4.9$ & $\begin{array}{l}\text { Next } 80 \\
\text { years }\end{array}$ & $\begin{array}{l}\text { - Increase in NPP and heterotrophic respiration; } \\
\text { - Small increase and in some cases decreased NPP in Mediterranean } \\
\text { type grasslands. }\end{array}$ \\
\hline $\begin{array}{l}\text { Thomson et al. } \\
\text { [52] }\end{array}$ & GCM & United States & 560 & $1-2.5$ & 2030-2050 & $\begin{array}{l}\text { - Overall increase in pasture production; } \\
\text { - Increase in crop production with higher atmospheric } \mathrm{CO}_{2} ; \\
\text { - Decrease in crop production with higher temperature. }\end{array}$ \\
\hline $\begin{array}{l}\text { Thivierge et al. } \\
\text { [54] }\end{array}$ & IFSM & Quebec (North America) & 639 & 1 & 2020-2079 & $\begin{array}{l}\text { - Overall increase in yield and decline in forage quality; } \\
\text { - Increase annual forage yield in colder areas, but decreased annual and } \\
\text { first-cut yields in warmer areas; } \\
\text { - Decrease in regrowth yield. }\end{array}$ \\
\hline Cullen et al. [55] & $\begin{array}{l}\text { SGS pasture model } \\
\text { and DairyMod }\end{array}$ & $\begin{array}{l}\text { Subtropical, subhumd, Mediterranean, } \\
\text { temperate, cool temperate (Australia) }\end{array}$ & $581-716$ & $0.7-4.4$ & 2030-2070 & $\begin{array}{l}\text { - Reduction in grassland production with } 10 \% \text { less rainfall, but a retained } \\
\text { production in Tasmania despite } 20 \% \text { a decrease in rainfall } \\
\text { - Greater grassland production by C4 species and extended growing } \\
\text { - } \quad \text { Deason in subtropical/subhumid regions; } \\
\text { highere in pasture production (up to } 19 \% \text { ) in southern Australia due to } \\
\text { - } \quad \text { Resilient pasture and less rainfall; }\end{array}$ \\
\hline $\begin{array}{c}\text { Moore and } \\
\text { Ghahramani [59] }\end{array}$ & GRAZPLAN & Southern Australia (Australia) & $451-635$ & 3 & 2030-2070 & $\begin{array}{l}\text { - Impact on production ranges from }-18 \% \text { to }+6 \% \text { by } 2050 \text {; } \\
\text { - Increase in the legume proportion of grasslands (high rainfall regions), } \\
\text { gross effect of greater legume content on nutritive value can be larger } \\
\text { than the likely changes in digestibility; } \\
\text { - Feed-base adaptations and combinations of different adaptations will be } \\
\text { required to maintain profitability. }\end{array}$ \\
\hline
\end{tabular}


Table 1. Cont.

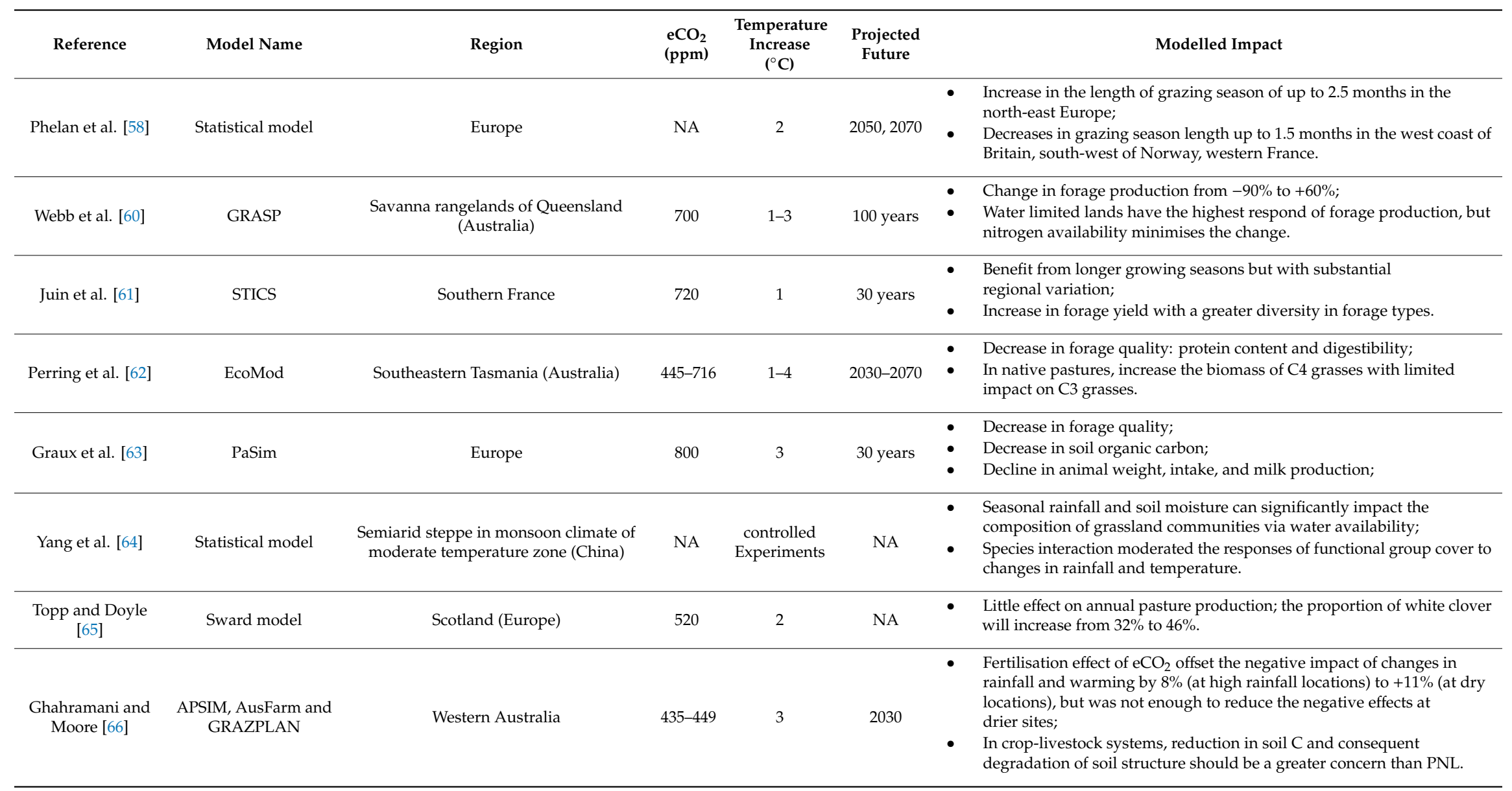


Although decreased soil moisture generally affects grass growth negatively, many regions in southern Europe appear to have a longer grazing season length. This effect is possibly due to strategic adaptation where livestock managers adopt to climatic stresses by reducing stocking rate or supplementary feeding and watering at pasture, rather than through the provision of housing for livestock. In Australia, shorter pasture growing seasons and consequently a reduction in the stocking rate is predicted [55]. However, reduction in the length of the growing season will be partly compensated by increases in production rate at the initial periods of the growing season [10]. Adaptive grazing management of livestock to avoid environmental degradation particularly in critical periods is an important factor that will influence outcomes for grassland plant communities and their productivity [60].

\subsection{Modelled Impact on Growing Season; Impact on Grassland Productivity and Quality}

The length of the growing season often correlates with overall livestock production, as longer seasons enable the year-round feeding of stock from pastures. Overall, temperate European grasslands are expected to benefit from predicted extended growing seasons under climate change [61] but with substantial regional variation. For example, Höglind et al. [67] noted the potential for an increase in grass yield in northern Europe, i.e., Iceland, Scandinavia and the Baltic region during 2040-2065, mainly as a result of increasing temperatures. However, due to the predicted increase in frost damage during winter, expansion of perennial grass is likely to be limited. Moreover, projections for future climate suggest the occurrence of cold acclimation for late autumn, under shorter photoperiods and lower light intensity that can affect the energy partitioning of grasses between the phenology stages and plant physiological functions [68].

In North American grasslands, increased temperatures are predicted to extend the growing season but with a corresponding decline in quality of forage (e.g., lower plant protein and digestible carbohydrates). Simulations indicated [69] that pasture production may increase by $5-15 \%$ by mid-century in northern regions due to longer growing seasons and more harvests per year. However, warmer temperatures and more intense storms could lead to greater nutrient losses to the environment. Furthermore, variations in rainfall suggest likely limitations in water availability [70,71]. The decrease in forage quality is related to a decline in available soil $\mathrm{N}$ and changes in life-form distribution functional groups and plant biochemical properties [71]. $\mathrm{eCO}_{2}$ is generally expected to increase the carbon: nitrogen ratio in plant tissues [72], while also reducing the overall quality of forage available for livestock. A meta-analysis [73] also indicated that $\mathrm{eCO}_{2}$ causes reductions in concentration of $\mathrm{N}$ and an increase in total non-structural carbohydrates, while it may not have a strong impact on digestibility and structural carbohydrats (NDF, ADF, ADL).

In addition to the field observations, modelling studies also suggest a decline in quality of forage under the impact of climate change in Tasmania in Australia [62] and Europe [63]. Cullen et al. [55] projected a shift in the plants growth pattern in south-eastern Australia, with increased winter growth rates. Moore and Ghahramani [10] found that such changes in the growth pattern would be widespread across Australian temperate grassland.

\subsection{Modelled Impact on Legume Content of Grassland}

The composition of grassland communities is expected to change with climatic changes, in particular in response to changing seasonal rainfall (e.g., [64]). Despite the apparent advantage for plants that fix nitrogen through microbial symbiosis under $\mathrm{eCO}_{2}$ scenarios, relatively few studies report modelled outcomes for grassland composition in relation to their legume content. This may be due to the uncertainty around nitrogen cycling under warming and $\mathrm{eCO}_{2}$ enrichment scenarios [39].

An Australian modelling study by Moore and Ghahramani [10,59] projected an increase in the legume proportion of grasslands, in particular, in high rainfall regions; they found that the gross effect of greater legume content on nutritive value could outweigh likely changes in digestibility. Topp and Doyle [65] found that, in Scotland, although global warming is projected to have small impact on the production of grass, white clover, as a percentage of total herbage production, was anticipated to increase from $32 \%$ to $46 \%$ in mixed grass-clover swards. 


\subsection{Modelled Impact on Grassland within Mixed Crop-Livestock Systems}

More recent studies have considered the impact of climate change on temperate pastures within mixed crop-livestock systems [66] which are widespread in the mid-latitudes of Africa, South America, and Australia. In Australia, results of modelling show that the fertilisation effect of $\mathrm{eCO}_{2}$ could offset the negative impact of changes in rainfall and warming by $8 \%$ (at high rainfall location) to $11 \%$ (at dry locations) [66]. However, the fertilisation benefit of $\mathrm{eCO}_{2}$ was not sufficient to recover the negative impacts at drier sites. In these crop-livestock farming systems, managing reduction in soil C (and consequent degradation of soil structure) should be a greater concern than PNL, particularly when PNL can be prevented by applications of $\mathrm{N}$ fertiliser in the cropping phase and can cycle via animal waste. In the mixed livestock-crop systems, crop residue is also consumed by livestock. The quality of crop residues is generally higher in seasons where crops have suffered from heat and moisture stress, due to carbohydrates retained in the unharvested material [74]. However, effects on forage $\mathrm{N}$ content have not yet been reported.

\subsection{Current Uncertainty in Modelling}

Even though the capacity of models to simulate the effects of climate change on grasslands has improved, there are still areas of uncertainty that are not well addressed. Recent studies $[75,76]$ have analysed the existing limitations of modelling approaches in European grasslands under climate change and highlighted their limitations in relation to: multi-species swards, some soil-plant-animal interactions (e.g., grazing pressure under extensive systems), overwintering, impacts of extreme events, plant pests and pathogens, and plant nutritional changes and their implications for animal performance.

Biophysical modelling has some limitations in representing a range of complex interactions among the biological components of grasslands. As mentioned previously, a range of outcomes for nitrogen cycling has been described under future climate scenarios, with the possibility that the key drivers may differ between bioregions and may depend on the nature of changing climatic and atmospheric conditions [39]. The use of simulation modelling with downscaled GCM models is common as a way to investigate climate change impacts on grassland scenarios. In addition to uncertainty related to the biological parameters of these models, downscaling GCM) data to the appropriate spatial and temporal resolution introduces an additional component of uncertainty [77].

Overall, the models are used for estimate the potential impact of climate change and effects of re-configurations in the systems on production, profit, GHG emission, and environmental consequences. However, models rely on both sound input of data and the quality of models and validation of the baseline scenarios. There is still a requirement for quantification of uncertainties and development of the current models to simulate, e.g., completion of the plants under the effect of $\mathrm{CO}_{2}$, PNL, and effects of heat stress on animals.

\section{Impact of Climate Change on Livestock Industries}

The effect of changes in climate on animals will be evident through the direct and indirect impacts on grassland production (explained in the previous section) and the direct and indirect effects on animals. The indirect effects on livestock come through impacts on fodder quantity and quality and pests and disease. The most important direct effects of climate change on animals would be thermal stress (cold and heat) and water availability, while the major indirect effects are expected to be from livestock diseases [7,78].

\subsection{Impact of Heat Stress on Animal Health and Production}

The heat stress is predicted to become a significant problem for both tropical and temperate livestock production systems in the future as global warming progresses, in particular with a continued prominence of genetic choice for traits with greater production [79]. Moreover, livestock systems based on grazing are expected to be more severely affected by increase in temperature than confined and industrialised systems [80]. With the probability of heat wave events predicted to increase in rate of 
occurrence and intensity [81], substantive effects of climate change and global warming on livestock productivity are expected [82].

Extreme temperatures during heat waves can result in significant livestock losses [83], including those related to productivity and reproduction, but also temperature-related illnesses and death. Guis et al. [84] have pointed to an increase in ruminant diseases in Europe related to changes in climate. This can be a limiting factor to design effective adaptation options as current biophysical modelling used for design of adaptations, in general, does not consider animal diseases. Overall, there has been little research published on observed impacts of climate change on livestock, particularly in relation to heat stress in animals and the efficiency of production [7].

Managing the impacts of the climate stresses on feed supply and thermal comfort in extensive grazing systems can ensure good outcomes for animal production and welfare. So far, most studies use the temperature humidity index (THI) as an indicator of heat stress in animals [85]. A range of adverse effects on productivity are reported when THI exceeding a threshold value. For sheep, these effects mainly include reduced feed intake [86], increased water intake [87], impairment of rumen functionality [88], restricted grazing range [89], prevented lactating behaviour (THI > 80) [90] and declined milk production [91]. These effects are likely to be smaller at dry regions of lower latitudes as animals have been through adaptations to heat stress [92].

Effects on animal production have been more extensively reviewed by Jolly [93], who described the importance of managing the thermal environments of grazing animals. Reproduction success may also be affected, with lower lambing percentages and lamb birth weight associated with elevated core body temperature [94]. For cows, this can be a decline in pregnancy rate when the average daily minimum temperature and daily THI index exceeding threshohlds [95].

\subsection{Impact on Animal Production Systems}

Moore and Ghahramani [10] showed that in the temperate grasslands of Australia, the effects of climate change on plant growth resulted in impacts on both pasture systems and livestock production. The reduced length of growing season together with changed temperatures caused a reduction in quality of the animals' intake. Therefore, it demands a decline in pasture utilisation (by less animal stocking rate) even in regions where rainfall is projected to increase. Also, the amount of above ground biomass that must be left unconsumed to protect soil surface increases as the gap between growing seasons become longer. Accepting a lower ground cover threshold would result in an unacceptable risk of soil erosion in this agricultural region. Moore and Ghahramani [10] found that climate changes increased intake conversion efficiency due mainly to increased legume proportion in pasture but this did not compensate for reduced pasture consumption. This resulted in a reduction in gross income, which reduced profit disproportionately because the grazing systems have substantial fixed costs. When upscaled for all of southern Australia, meat production from Australian temperate pastures was projected to decline by $20 \%, 26 \%$, and $38 \%$ at 2030,2050 , and 2070 , respectively, when no adaptation implemented in the current systems.

\section{Adaptations to Climate Change in Grassland and Livestock}

In grazing systems, adaptations to climate change can be grouped into feed base and livestock adaptations, noting that these interact with each other. These adaptations include genetics (via breeding or introducing existing genotypes) and management, as compared in Table 2.

\subsection{Integrated Grassland and Livestock Adaptation}

Adaptation to climate in grassland and livestock systems are a response to the integrated effects of changes in the atmosphere, e.g., $\mathrm{eCO}_{2}$, changes in climate such as rainfall and temperature, and an increase in climate variability. Incremental adaptations (simple adjustments to existing farming systems [96]) which are applicable on a range of timescales can be one-off activities [8] or may be on a historical trend of progress, for example animal genetic improvement [97]. 
Table 2. Climate change adaptation options in temperate grazing systems.

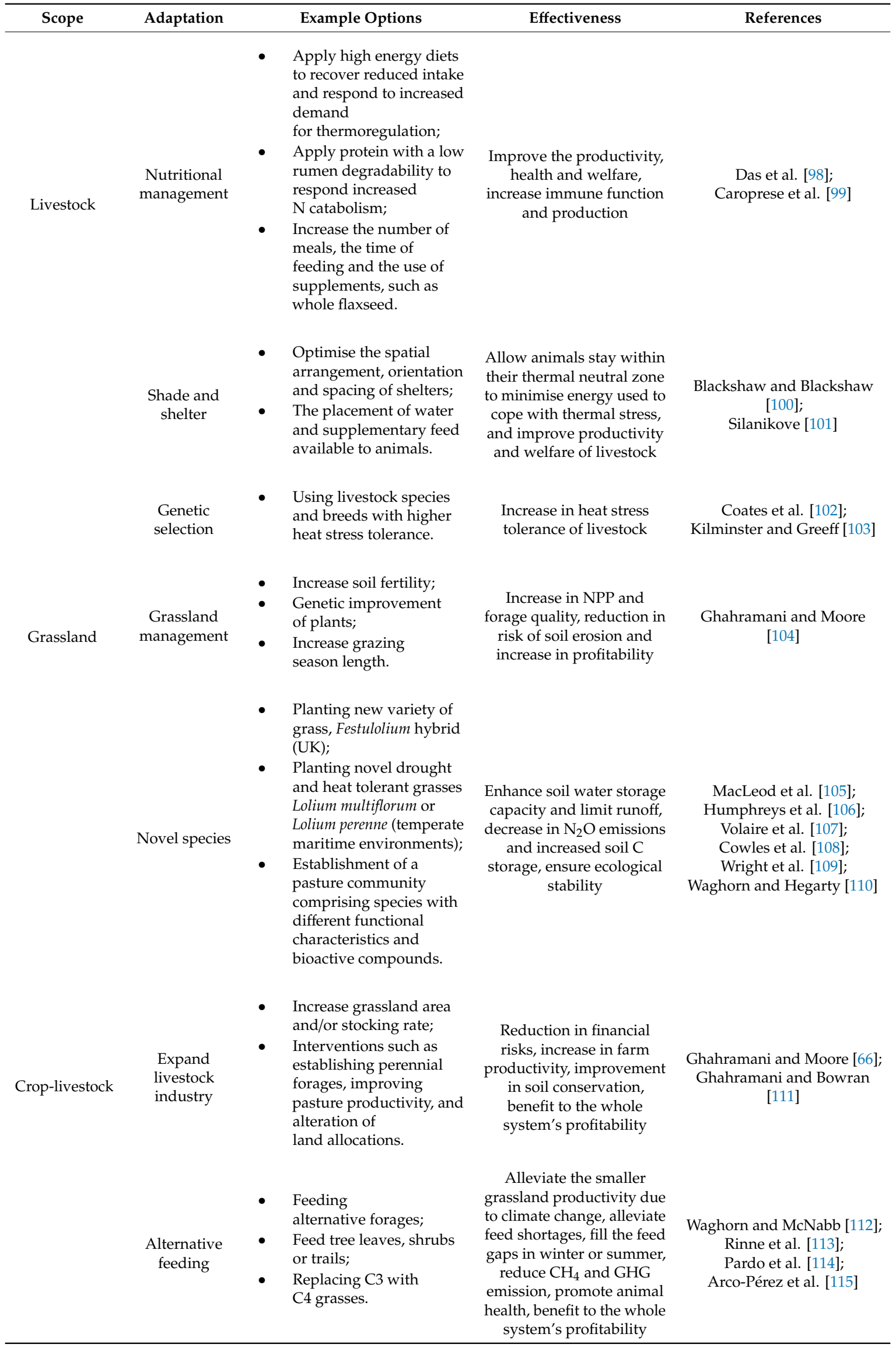


While single incremental adaptations (e.g., increase in grassland fertility) are likely to be particularly effective in high rainfall areas, a systemic integration of multiple adaptations (e.g., a combination of an increase in grassland fertility and animal reproduction rate) can result in significant increases in production and profit [116]. This is particularly the case in drier regions of Australia where greater impacts of climate change are expected on farming systems that are more vulnerable to climate change in comparison with those in high rainfall regions [116].

\subsection{Adaptations through Animal Feeding}

Enhancement in nutritional value of animal intake and breeding for heat-resistant animals can be key strategies to maintain and improve the productivity and welfare of livestock. Das et al. [98] have identified a range of nutritional strategies to cope with high temperatures. These are animal diets with high energy to recover decline in quantity of feed and higher energy demand for thermoregulation, addition of a low rumen degradability protein to compensate for increased $\mathrm{N}$ catabolism. Also, this can include increase in frequency and time of feeding, and addition of supplements to meals e.g., whole flaxseed [99] to enhance immune function and productivity.

\subsection{Adaptations in Grasslands}

The grassland adaptations will often emphasis to increase NPP and forage quality (or at least limit reduction in these) and/or minimise the frequency and length of the periods of low ground cover to minimise the risk of soil erosion [10]. Ghahramani and Moore [104] indicated that by 2030, changes in management (including increased soil fertility and at least one genetic improvement) could potentially reduce risk and fully recover profitability of the grazing system to its historic level over the majority of the regions studied. Hence, livestock systems would potentially be adopted with multi-level adaptation strategies to minimise negative impacts $[8,116]$. However, increased grazing season length as an adaptation choice may also result in increased exposure to helminth parasites which may be associated with reduced milk yields and decreased production efficiency, thus, increasing GHG emission intensity (EI) [117].

\subsection{Adaptation in Grasslands by Novel Species}

In many regions, climate change may result in lower or more variable soil moisture availability. New grass varieties have demonstrated capacity to improve water use efficiency. MacLeod et al. [105] conducted a two-year field experiment in the UK testing a new variety of grass, Festulolium hybrid, capable of reducing runoff in range between $40 \%$ and $50 \%$, compared to the recommended cultivars Lolium perenne and Festuca pratensis. These cultivars exhibited a faster growth rate and turnover of roots resulted in a higher capacity for storing soil water and low runoff production.

Novel drought and heat tolerant grasses from Mediterranean regions such as Lolium multiflorum or Lolium perenne together with Festuca arundinacea var. glaucescens can be used to cope with climate change in temperate maritime environments [106]. Most native grassland populations contain a high diversity of grassland species for tolerating drought [118] and therefore, breeding or long-distance migration of grass species may not necessarily be required. In areas with severe environmental stresses, the establishment of a pasture community comprising species with different functional characteristics can help ensure that ecological stability is a key adaptation measure to climate change [107]. Overall, plant diversity can act as a safeguard of ecosystem functioning [107] for heat stress [108] and flooding events [109].

It is also possible to reduce the detrimental effects of livestock farming on environment through application of novel pasture systems and use of plants with high nutritive value and bioactive compounds. Several pasture plants such as chicory, plantain and birdsfoot trefoil are well-suited to the temperete climatic conditions and can offer multiple benefits for animal production, animal health and mitigation of environmental problems such as $\mathrm{N}$ leaching and methane emissions. There is ample scientific evidence that tannin-containing plant species such as chicory and birdsfoot trefoil 
can help reduce methane emissions from grazing animals [110]. Reduction in urinary $\mathrm{N}$ can also be achived though feeding livestock pastures or TMR containing birdsfoot trefoil or chicory. The bioactive compounds in particular condensed tannins help shifting routes of $\mathrm{N}$ from urine to feces [119]. This is particularly important to reduce $\mathrm{N}$ leaching problems in pastures. Similarly, grazing plantain causes less intensive nitrous oxide deposition from the cows potentially leading to less $\mathrm{N}$ leaching problems due to its diuretic effect [120].

\subsection{Adaptation by Managing Heat Stress on Animals}

The microclimates provided by shade and shelter allow animals to stay within their thermal neutral zone and minimise energy used for heating or cooling to alleviate thermal stress [100]. While providing shelter and shade is straightforward, ensuring that animals use this resource effectively to reduce thermal stress without causing unwanted environmental or other impacts is harder. For example, it may be possible to improve the animal's use of shade by optimising the spatial arrangement, orientation and spacing of shelters, the mixture of both woody vegetation and forage shrubs, and the placement of water and supplementary feed without creating overgrazed areas [100]. Furthermore, integrated production systems such as silvopastoralism or agrivoltaics (agricultural production under solar panels) can be adopted as a means of providing shade and windbreak. These systems can also increase the efficiency of land use through producing energy and animal products from the same land [121].

The provision of shade is an effective means to enhance the welfare and productivity of sheep in extensive grazing systems. Sheep will seek shade if it is available and best-practice suggests that it is essential that shaded areas are available to adequately provide for the welfare of animals when temperatures exceed $24^{\circ} \mathrm{C}$ [101]. If the shade is not available, sheep will adopt postures and grouping behaviours to improve their thermal comfort but which may reduce intake and productivity [101]. Direct benefits of reduced heat stress through the provision of shade on lamb birth weight and survival have been reported [122].

Some livestock (e.g., B. indicus cattle) are able to be productive in hot climates due to a range of mechanisms, including increased skin surface area to body weight, physiological mechanisms to transfer internal heat to the skin, light-coloured coats to reduce heat loads, adjusting cellular mechanisms and a range of behavioural strategies [82]. In adaptation to heat stress, an effective proposition could be avoiding a single trait breeding to prevent from breeding animals with lower heat tolerance at the expense of production potential [123].

Because heat stress is a significant limiting factor, the selection of cattle species and breeds suited to tolerate heat stress has been an important management strategy in hot and humid climates. For example, in Northeastern Australia, the Belmont Red hybrid breed was developed to increase cattle productivity through greater heat tolerance, parasite resistance and resilience to periodic severe under-nutrition [102]. The Damara and Dorper sheep breeds were also introduced to Australia during the 1990s due to their suitability for arid-type environments with extreme temperatures and variable feed quality [103]. These types of adaptation are expected to become more widely used with projected global warming.

\subsection{Adaptation in Livestock Systems}

Many researches have observed and predicted declines in pasture production with climate change suggesting a need to adopt sustainable stocking rates - in general lower - to avoid potential risks of soil erosion. Moore and Ghahramani [97] introduced potential adaptations options via genetic improvement of current breeds, considering their historical trends: increased body size, fleece growth or and conception rate, and avoidance of heat stress. Modelling results have indicated that the most economically effective option varied between the livestock enterprises [97]. In different sheep enterprises, breeding for greater fleece growth was the most beneficial option, while in cattle systems it was breeding for larger body size. Increased conception rates were less effective but potentially useful adaptations in beef cow and crossbred ewe systems. In the Mediterranean environment, where 
summers are dry, breeding for a greater tolerance to heat stress may not improve the productivity noticeably in the short-medium term because of the relatively small gains that may be associated with increases in temperature expected during the next several decades. As with the grassland adaptations, the financial effectiveness of the genetic improvement of livestock would be the least to offset the impact of changes in climate at drier locations where the requirement for climate change adaptation is likely to be the greatest [97]. However, it is likely that improving genetic resilience to heat stress would benefit existing patterns of extreme temperature events.

Livestock enterprises can be modelled for operating at the efficiency frontier. The efficiency frontier is the maximum potential level of profitability (or another output metric) for a given level of input for the system under consideration [124]. Currently, many Australian graziers operate their systems with conservative stocking rates and with risk management that results in them operating well below the efficiency frontier $[10,125]$. For these farmers, an improvement in management toward the efficiency frontier (i.e., intensive management) can be an effective approach as adaptation strategy.

\subsection{Adaptation in Mixed Crop-Livestock Systems}

There are grazing systems across the world are integrated with cropping, and adaptations to climate can occur in either the crop or livestock component of the system (or both). In Africa, changes in climate associated with increased rainfall can favour cropping [126]. In Australian mixed farm systems (mostly dryland), livestock has been found to be less sensitive (than cropping) to changes in climate and thus would continue to be a risk-avoidance strategy [127]. Therefore a shift towards increased livestock (i.e., grassland area and/or stocking rate) may be a strategy for managing the financial risks associated with changes in climate $[66,111,128]$. However, Thamo et al. [129] found that under future climate scenarios the re-allocation of land in south-western Australia from cropping to sheep production would probably not occur, and that the most profitable farm stocking rates would be lower due to a reduction of feed produced and a greater need to conserve biomass for soil protection (ground cover). Interventions such as establishing perennial forages, improving pasture productivity, and alteration of land allocations have been found to jointly improve farm productivity and soil conservation in these farming systems $[111,130]$. It is possible to mitigate the negative environmental effects of livestock farming through better integration of crop-livestock systems in pasture based livestock production. Cheng et al. [131] reported lower estimated urinary $\mathrm{N}$ excretion from dairy heifers that grazed canola (52.5 g/day) and wheat ( $59.1 \mathrm{~g} /$ day) as compared to perennial ryegrass-white clover pasture $(98.9 \mathrm{~g} /$ day). This indicates that integrating annual crops in pastoral systems can potentially decrease $\mathrm{N}$ losses by reducing the $\mathrm{N}$ loading into urine patches.

\subsection{Adaptation and GHG Emissions}

Adaptation strategies will, however, impact on GHG emissions [116]. The full adoption of climate change adaptation options will often involve increasing stocking rates towards the efficiency frontier and this can increase ruminant $\mathrm{CH}_{4}$ emission rates per unit area (e.g., from the historical baseline of $70 \mathrm{~kg} \mathrm{ha}^{-1} \mathrm{yr}^{-1}$ to 84,83 , and $75 \mathrm{~kg} \mathrm{ha}^{-1} \mathrm{yr}^{-1}$ in 2030, 2050, and 2070 respectively [116]). Potentially, higher $\mathrm{CH}_{4}$ emissions can affect profitability of the systems depending on the occurrence of future emissions pricing. In the UK, del Prado et al. [132] evaluated the effect of options under impacts of future climate change on grassland productivity and growth length. These measures were proposed to increase the grazing period, could result in in a modest decrease in GHG emission, but substantially larger losses through $\mathrm{NO}_{3}$ leaching compared to the non-adapted scenarios.

In order to alleviate the smaller grassland productivity due to climate change, feeding alternative forages (e.g., [112]) or agro-industry by-products [113] are potential measures for the adaptation of grassland-based livestock systems. Both embedded GHG emissions from feed production and resulting GHG emissions from animals, e.g., enteric $\mathrm{CH}_{4}$ or soil i.e., $\mathrm{N}_{2} \mathrm{O}$, may also be affected. Feeding animals with tree leaves and shrubs can alleviate feed shortageswhile some of these may contain levels of compounds such as tannins that can suppress enteric $\mathrm{CH}_{4}$ emissions and promote animal health [112]. 
However, this option should be approached cautiously as excees amount of dietary concentration of condensed tannins may have detrimental effect on animal production [133]. For dairy goat systems, Pardo et al. [114] analysed a dataset from a feeding trial [115] and by applying life cycle analysis (LCA), found that replacing oats and hay with tomato by-product silage in the diet reduced the $C$ footprint by decreasing $\mathrm{N}_{2} \mathrm{O}$ emissions during the cultivation stage. Bell et al. [134] suggested replacing $C_{3}$ with $C_{4}$ grasses as an adaptive option to maintain productivity and minimising GHG emissions.

\section{Ecosystem Health of Grasslands under Climate Change}

The environmental issues in grasslands are different within and between regions across the world. For example, in intensively managed perennial ryegrass pastures of northern Europe, off-site loss of nutrients is an issue [135]. In these high input systems, the impact of climate change can be limited by changes in regulations and financial drivers of nutrient application rates. In less-intensive managed temperate grasslands, e.g., in southern Australia, there are concerns for different factors of ecosystem health. Soil erosion can be a significant problem in these regions, in particular, in Mediterranean-type climatic zones where rainfall is limited, surface soil is dry for long periods, and soils lose cover required for protection as ground cover breaks down [136]. The projected reduction in grassland biomass and cover and shorter growing seasons described above suggest a progressive increase in the frequency of days with low ground cover (less than 70\%) over the 21st century [116]. This will cause a risk of soil erosion [137]. Climate change adaptations in grassland increase production and hence profit through increased NPP and this can offset declines in ground cover and frequency of days with low cover, at least to some extent $[111,116]$. A shift toward a greater alfalfa proportion in pasture as an adaptation option should be treated with caution as it may exacerbate decline in ground cover. Compositional changes to legume dominant grassland, whether caused by plant competition or the establishment of legume species as an adaptation to climate change, may result in soil acidification [138].

At present, most grassland models do not consider the value of ecosystem services from grasslands $[75,139]$. There is also lack of quantified knowledge about the effect of climate change on ecosystem services and the potential interactions between factors of ecosystem services [140]. Lamarque et al. [141] analysed the effect of climate change on bundles of subalpine grassland ecosystem services, e.g., economic values of water and soil conservation using plant trait-based models. They found that the impacts of climate change on ecosystem services were larger than management changes, e.g., grazing or fertilisation strategies. In their report, some indicators were predicted to increase, e.g., $\mathrm{N}$ mineralisation or soil organic matter, but plant diversity and flowering onset decreased.

\section{Modelling GHG Emission}

Farm-scale models of grassland-based ruminants have been applied to quantify total GHG emissions. Their main features, constraints and capabilities are, for example, discussed in del Prado et al. [139]. These type of models are capable of simulating GHG emissions in different production systems in temperate grassland and their livestock across the world [132,142-144]. Some findings from these studies indicate, for example, that with similar animal production, greater enteric emissions from grazing-based systems are offset by lower manure emissions (confined systems) to provide a lower $C$ footprint for milk produced in grazing systems (e.g., [145]). Intensification-wise, Harrison et al. [146] concluded that the best strategies for both sustainably increasing production and reducing emissions were those related to interventions that shift the balance of the flock away from adults and towards juveniles while holding average annual stocking rates constant. In studies such as Zehetmeier et al. [147] and del Prado et al. [139], large differences were found when different approaches were used to predict enteric $\mathrm{CH}_{4}$ or to estimate $\mathrm{N}_{2} \mathrm{O}$ emissions. Similarly, including the changes in soil carbon of grasslands would affect the total on-farm GHG balance [139].

Farm-models have also been used for simulating livestock production and GHG emissions under climate change scenarios [148], integrating climate impacts and adaptation measures with mitigation-based strategies $[149,150]$. Some models may capture animal weight loss attributable to 
climatic effects caused by changes in feed composition, but only a few models include the effects of heat stress on animal DM intake e.g., during grazing [63]. A very few, to our knowledge, can simulate the effect of other climatic factors, such as wind chill or cold stress on animal performance [151]. Accurately representing production and GHG emission levels, under climate historic and forecast climate scenarios is important in assessing GHG emissions intensity, or the level of production for a given amount of carbon released.

\section{Mitigation}

Globally, $\mathrm{CH}_{4}$ is the second most important anthropogenic GHG in terms of its role in global warming, and ruminants are the largest source of its emissions. The amount of $\mathrm{CH}_{4}$ emitted from livestock systems accounts for about $44 \%$ of sectoral emissions [19]. Ruminant $\mathrm{CH}_{4}$ emission depends on the feeding systems, efficiency of production, animal number (stocking rate) and where climate change, without adaptations causes a decline in livestock stocking rates, $\mathrm{CH}_{4}$ emission per unit of area is expected to decline, e.g., across Australian temperate grasslands in the range between 1\% to 12\% [116].

\subsection{Emission Reduction Options}

The diversity of livestock production systems and variations in technical, managerial, financial and policy situations means that emission-reduction is likely to be contextual [9]. In particular, emission reduction options vary depending on the component of emissions being targeted: a focus on $\mathrm{CH}_{4}$ reduction will raise different options than seeking primarily to increase soil $\mathrm{C}$. However, the options will often interact with each other and so methods that allow comparison of different GHG such as $\mathrm{CO}_{2}$ equivalents can be used to assess the net emission consequences of specific management strategies. There are also different metrics for evaluation of emission-reduction: absolute emissions (i.e., $\mathrm{kg} \mathrm{CH}_{4}$ ) or total emissions (i.e., carbon dioxide equivalents) in terms of the farm or the value chain or emission efficiency (i.e., $\mathrm{kg}$ emissions per unit of product or per unit value or per unit land area). Therefore, it is important to carefully explain the scope of any emissions scenarios, and ensure results are framed in the correct context.

Enteric methane is mainly emitted as a by-product of ruminant digestive processes, constituting a significant loss of energy from the animals - typically $6 \%$ to $7 \%$ of gross energy intake [152]. Consequently, there has been extensive research into technical options for emission-reduction over a period of decades [153]. These include provision of additional dietary oils [154], ionophores and other additives [19] including 3-nitrooxypropanol (3NOP) [155], nitrates [156], tannins and saponins [157], specific shrubs and pasture species with anti-methanogenic properties [154,157], higher digestibility forages and feedstuffs such as red-algae [158], anti-methanogenic vaccines [159] and genetic selection for lower emissions [160]. These options vary in their effectiveness (up to $30 \%$ reduction but most reduce emissions by $5 \%$ to $10 \%$ ) and availability, and many of them are impractical or unsuited to extensively grazed livestock systems. There are also opportunities in more intensive systems to reduce $\mathrm{CH}_{4}$ emissions via an increased level of concentrates in livestock diets, improved feed formulation and processing, and enhanced forage quality and management [19]. These options, along with enhanced animal husbandry (management of pests, diseases, harsh climate and other conditions) often increase feed energy intake and hence $\mathrm{CH}_{4}$ emissions. However, they tend to increase the energy available for production to a much greater extent, thus resulting in marked increases in emissions efficiency [161]. This increase in emissions efficiency is in many situations the most immediate, practical and cost-effective route to emissions mitigation, often aligning with economic incentives and trends for increased productivity and achievement of product quality specifications [162]. Increased emissions efficiency is also frequently associated with reduced large-scale environmental impacts [163], providing the stocking rate is not increased.

\subsection{Excreta Management}

Methane, along with $\mathrm{N}_{2} \mathrm{O}$, is also emitted from intensive livestock manure systems, and there are often non-GHG emission incentives to reduce this, sometimes associated with off-site odour problems 
and in other cases because the $\mathrm{CH}_{4}$ can be captured for energy production. There are several technical options to reduce these emissions, reviewed by Gerber et al. [164]. These include enhanced manure storage (e.g., aeration, reduced residence time), composting, anaerobic digestion, biofiltration, manure spreading on pasture, urease and nitrification inhibitors, and dietary manipulatio to reduce and/or change the organic carbon and nitrogen waste volume and characteristics.

\subsection{Managing Carbon Stocks}

In addition, there exist a large range of other management and policy options that impact on other parts of livestock emission budgets such as below ground and aboveground carbon stocks or that interact with potential climate change adaptations (Table 3). Importantly, most of the mitigation options associated with increased carbon stocks interact positively with climate change adaptation options as also found by Smith and Olesen [165]. However, realising these synergies is likely to require significant enhancement of managerial capacity, directed research, development and, by extension, in some cases significant capital investment, institutional development, clarification of property rights, and emission verification and pricing [166]; all of these can be influenced positively by appropriate settings policy.

\subsection{Mixed Farming Businesses}

The mixed farming industry has had relatively less attention in terms of climate change mitigation compared to the extensive cattle grazing enterprises, even though they can be of a significant size. For example, the GHG emission from broadacre sheep farms, Australia's predominant livestock enterprise in the mixed farming region, constitutes around 16\% of Australia's total livestock emissions [167]. Climate change may force a decrease in GHG through a decline in animal numbers [116], but possible profitable adaptation options would counter this tendency, especially if international demand and the price for meat and wool remains strong (Table 3).

\subsection{Integration of Adaptation and Mitigation}

Whole-farm models [23,66,144,168] and life cycle assessment based approaches [169] are valuable tools to study the integration of both mitigation and adaptation strategies to climate change for livestock grassland-based production systems. However, most whole-farm models still do not include all of the responses to climatic drivers. Although these responses are connected to grassland productivity and quality, it might be desirable to include all the relevant processes that affect the flows and transformations of carbon and nitrogen within the farm, such as those undertaken by Ghahramani and Moore [66]. Destocking as a mitigation strategy may fail to account for the loss of opportunities for adaptation through the establishment of forage shrubs and other perennial forage species [144]. Establishing perennial forage species has been identified as a significant opportunity internationally for carbon sequestration and reducing enteric methane emissions [170-172].

Cottle et al. [173] examined a range of grazing systems that are suitable for climate change adaptations. They reported that, for example, increasing soil phosphorus fertility and increased portion of alfalfa in grasslands could result in $-66 \%$ and $+113 \%$ changes in GHG/dry sheep equivalent, respectively, while, breeding ewes with larger body size or genotypes of higher fleece weight could result up to $11 \%$ and $9 \%$ reductions in emission intensity, respectively. They suggested that animal breeding options can reduce EI more effectively than feedbase management.

\section{Recommendations}

This review identifies research gap recommended by recent literature. Our recommendations highlight key aspects of the review and put forward the case fordirections of future research on climate change in temperate grazing systems, as presented in Table 4. 
Table 3. Management and policy options that impact livestock emission budgets.

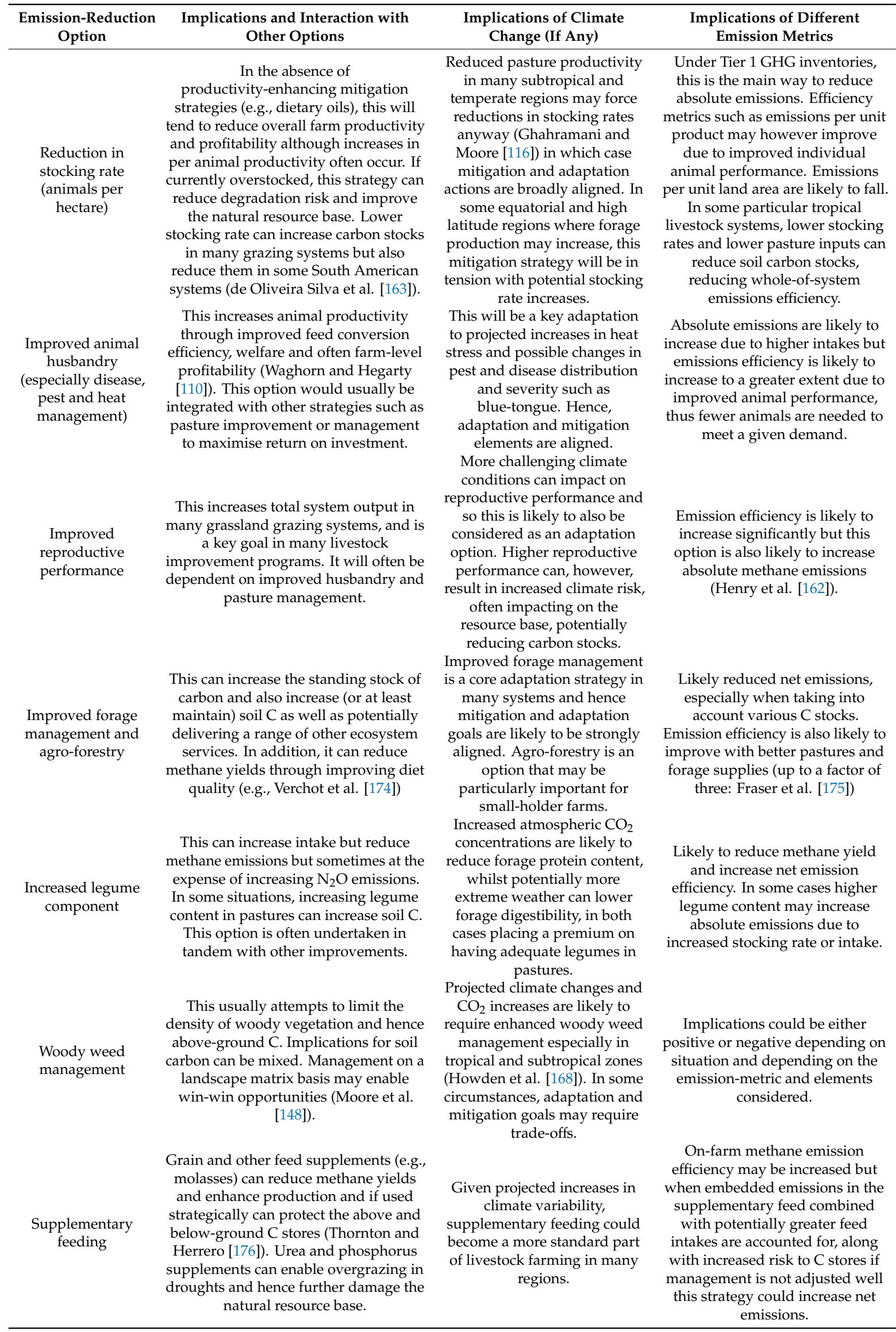


Table 3. Cont.

\begin{tabular}{|c|c|c|c|}
\hline $\begin{array}{l}\text { Emission-Reduction } \\
\text { Option }\end{array}$ & $\begin{array}{l}\text { Implications and Interaction with } \\
\text { Other Options }\end{array}$ & $\begin{array}{l}\text { Implications of Climate } \\
\text { Change (If Any) }\end{array}$ & $\begin{array}{l}\text { Implications of Different } \\
\text { Emission Metrics }\end{array}$ \\
\hline $\begin{array}{c}\text { Enhanced } \\
\text { robustness and } \\
\text { efficiency of } \\
\text { livestock value } \\
\text { chain }\end{array}$ & $\begin{array}{l}\text { Improved input and output } \\
\text { management and including externalities } \\
\text { as part of food footprint-type } \\
\text { approaches could require systemic } \\
\text { change in farming systems, bringing } \\
\text { into play several of the above strategies } \\
\text { (Garnett [177]). Improving livestock } \\
\text { value chains is seen as a key poverty } \\
\text { and nutritional insecurity alleviation } \\
\text { strategy in many developing countries. }\end{array}$ & $\begin{array}{l}\text { Projected increases in climate } \\
\text { variability may require } \\
\text { buffering strategies across } \\
\text { value chains and spatially as } \\
\text { well as closer attention to } \\
\text { meeting market specifications. } \\
\text { Hence, mitigation and } \\
\text { adaptation are likely to be } \\
\text { broadly aligned. }\end{array}$ & $\begin{array}{l}\text { Changes in value chains could } \\
\text { result in either decreases or } \\
\text { increases in total emissions. There } \\
\text { are likely to be incentives to } \\
\text { increase emission efficiency } \\
\text { associated with food-footprint } \\
\text { metrics. }\end{array}$ \\
\hline
\end{tabular}

Table 4. Example of recommendations for future research.

\begin{tabular}{|c|c|c|c|}
\hline Scope & Topic & $\begin{array}{l}\text { Related } \\
\text { Section in } \\
\text { this Paper }\end{array}$ & References \\
\hline \multirow{3}{*}{ Grassland } & $\begin{array}{l}\text { - Compositional change of plant } \\
\text { communities under } \mathrm{eCO}_{2}\end{array}$ & 2.1 & Morgan et al. [30] \\
\hline & $\begin{array}{l}\text { - PNL To understand the plant-animal } \\
\text { interactions (in FACE experiments) }\end{array}$ & 2.3 & Nowak et al. [32]; Newton et al. [33] \\
\hline & $\begin{array}{l}\text { - Yield and nutritional quality of forage } \\
\text { to explore the complex plant physical } \\
\text { and chemical characteristics in plant } \\
\text { growth affected by eCO} 2\end{array}$ & 2.3 & Barbehenn et al. [40]; Newton et al. [33] \\
\hline Livestock & $\begin{array}{l}\text { - } \quad \text { Direct impacts of climate change: } \\
\text { - } \quad \text { heat stress on animals and the } \\
\text { efficiency of production, disease } \\
\text { - } \quad \text { issues with changes in growing season }\end{array}$ & $\begin{array}{l}2.7 \\
3.1 \\
3.2 \\
5\end{array}$ & $\begin{array}{l}\text { Moore and Ghahramani [10,59]; } \\
\text { Ghahramani and Moore [97]; } \\
\text { Chappell et al. [136] }\end{array}$ \\
\hline \multirow{2}{*}{$\begin{array}{l}\text { Mixed-systems } \\
\text { (Australia) }\end{array}$} & $\begin{array}{l}\text { - Quality of crop residues under } \\
\text { climate stress }\end{array}$ & 2.10 & Purser [74] \\
\hline & $\begin{array}{l}\text { Risk of soil erosion and implications } \\
\text { for groundcover and soil C dynamics }\end{array}$ & 4.7 & $\begin{array}{l}\text { Ghahramani and Moore [66]; Ghahramani } \\
\text { and Bowran [111]; Thomas et al [130] }\end{array}$ \\
\hline GHG emission & $\begin{array}{l}\text { Developing practical and suitable } \\
\text { mitigation options for } \\
\text { extensively-grazed livestock systems } \\
\text { e.g., increase the emission efficiency } \\
\text { Establishing appropriate adaptation } \\
\text { and mitigation policy considering } \\
\text { mixed farming business }\end{array}$ & $\begin{array}{l}7.1 \\
7.4\end{array}$ & $\begin{array}{l}\text { Rivera-Ferre et al. [9]; Grainger and } \\
\text { Beauchemin [154]; Gerber et al. [164]; } \\
\text { Van Zijderveld et al. [156]; } \\
\text { Beauchemin et al. [178]; Banik et al. [157]; } \\
\text { Durmic et al. [158]; Wedlock et al. [159]; } \\
\text { Basarab et al. [160]; DoE et al. [167] }\end{array}$ \\
\hline Modelling & $\begin{array}{l}\text { - } \\
\text { drivers such as ENSO or the Indian } \\
\text { Monsoon in GCMs } \\
\text { Quantification of the uncertainty } \\
\text { e.g., downscaling } \\
\text { Development of current models to } \\
\text { simulate e.g., competition of plants } \\
\text { under the effect of } \mathrm{CO}_{2}, \mathrm{PNL} \text {, impacts } \\
\text { of heat stress on animals, also to } \\
\text { enable simulation of } \\
\text { ecosystems services } \\
\text { To assess ruminant/animal diseases } \\
\text { under climate change }\end{array}$ & 2.11 & $\begin{array}{l}\text { Kipling et al. [75,76]; Polley et al. [39]; } \\
\text { Claessens et al. [77]; Guis et al. [84]; } \\
\text { del Prado et al. [139]; Pilgrim et al. [140] }\end{array}$ \\
\hline
\end{tabular}




\subsection{Grassland}

In relation to the research on grassland, a comprehensive understanding about the species responses to changes in climate within swards is still required to predict compositional change under $\mathrm{eCO}_{2}$. A clear distinction between the biomass responses to direct and indirect $\mathrm{eCO}_{2}$ effects needs to be considered in future studies [30]. More FACE experiments are expected in future research to understand e.g., PNL under plant-animal interactions in the grassland under grazing [33]. Moreover, to manage the production and quality of forage, there is need for research on physical and chemical characteristics of plant growth affected by $\mathrm{eCO}_{2}$ [40]. These studies can also include quantification of regional variations and comparison of nutritious between $C_{3}$ and $C_{4}$ grasses. In design of adaptation options with introducing legume species, the risk of soil acidification and reductions of groundcover should be considered.

\subsection{Livestock}

In extensive livestock systems, more research is required to focus on the direct effect of heat stress on animals and consequent impact on production efficiency [7], and the problems resulting from potential changes of growing seasons and gaps in feed availability [10]. To cope with reductions in the length of growing season and NPP (e.g., in Australia), the risk of soil erosion should be considered and controlled in the adaptations adjusting ground cover threshold, particularly in relation to grazing intensity [10]. Further research is required to focus on impact of climate change on animal diseases, and welfare generally, as previously there are a limited number of previous studies $[78,84]$.

\subsection{Mixed Systems}

For mixed crop-livestock systems, recommendations are made to focus on reduction of the climate change impact at dry regions where the fertilisation effect of $\mathrm{CO}_{2}$ on plant growth is predicted to be insufficient [66]. To manage wind and water erosion risks in mixed systems, future research may focus on developing integrated management tactic e.g., pasture legume content and soil fertility, ground cover, identifying critical periods of wind erosion risk, and balanced use of residues and biomass [130]. As most of the current profitable adaptations may not be the most environmentally sustainable, an integrated approach including economic, climate analysis, advancement in technology, environmental management, and GHG emission will be needed in the development of adaptations in mixed crop-livestock farming systems [111].

\subsection{Mitigation}

The mitigation of GHG emission from livestock also needs further research, especially for extensively-grazed livestock systems. Practically, increases in emissions efficiency is still one of the most suitable approaches. Future research may also be framed in relation to the design of emission-reduction scenarios, and paying more attention to critical question as why producers and consumers are not adopting the established methods, and what policy can enhance implementations [9]. In addition, further development of policies is necessary for realising the synergies of increased carbon stocks caused by mitigation options and climate change adaptations [167]. Implementation of treatments to modify rumen microbial processes, such as feeding ruminants with red algae, asparagopsis is an area that can be explored [167].

\subsection{Modelling (Development and Modelling Method)}

Model development, as one primary approach to assess the effect of climate change and design effective adaptations, can be optimised in several areas. Overall, the quantification of uncertainty in modelling climate change impacts and adaptations is still insufficient $[75,76]$. Current models require further development to simulate various biophysical components e.g., competition of the plants under the effect of $\mathrm{CO}_{2}, \mathrm{PNL}$, and the impacts of heat stress on livestock [77]. To model the impact of 
legume content of grazing lands, the modelled outcomes for plant composition should minimise the uncertainty around nitrogen cycling [39]. Future grassland models should also consider the value of ecosystems services, and quantify the effect of climate change on ecosystem services and the potential interactions $[75,139,140]$. Future livestock models should consider climate impacts on ruminant and animal diseases (e.g. parasites) as one of the key processes [84]. Moreover, the future GHG emission models should quantify the variation of different approaches for the prediction of enteric $\mathrm{CH}_{4}$ and $\mathrm{NH}_{3}$ emission, consider the changes in soil carbon in grasslands, and include the effects of heat stress on animal dry matter intake $[63,151]$. Finally, future whole-farm models are expected to include all the responses to climate drivers connected to grassland productivity and quality, the processes that could affect the flows and transformations of carbon and nitrogen within the farm and the impacts on livestock farming in relation to diet feeding and heat stress.

\section{Conclusions}

Based on the literature we reviewed, atmospheric and climate change are likely to have overall negative impacts on productivity and profitability of temperate grasslands and livestock production globally, although specific regions may benefit with particular levels of climate change. In order to gain benefits in livestock production under moderately elevated $\mathrm{CO}_{2}$, improvements in the photosynthetic rate of forage plants, soil nitrogen and the supply of other nutrients needs to be maintained. As was suggested from the studies in our review, this may require plant compositional changes and careful animal and soil nutrient management, for example, the incorporation of new forage legumes in pastures, and livestock business that apply careful grazing practices with improved tactical management skills.

Research into climate change in managed grasslands and their livestock has largely been limited to Australasia, Europe, and North America. The exceptions, such as those of Field et al. [179], have not taken into account the diversity of species and their physiological responses to climate change as they were global studies. Large areas of temperate grasslands exist in China, south-west Asia, Africa, and South America, for which there are little knowledge of the impact of climate change, let alone effectiveness of potential adaptation options. Most of these grasslands are being managed at a lower intensity compared to those in European or North American systems and commonly are within mixed crop-livestock systems.

There are many technical options to reduce GHG emissions such as feed additives, anti-methanogenic vaccines, and the selection of lower-emitting animals. In addition, a range of husbandry and feed management options such as effective stocking rates, pasture and woody species management and pest control may improve emissions efficiency. In many situations, these are the most immediate, practical and cost-effective options to reduce emissions, often improving productivity and bringing economic benefits. Importantly, these options also frequently (but not always) align with effective climate adaptation strategies. There is a clear and present need for cross-scale research into the direct and indirect impacts of climate change on livestock and the grasslands they inhabit.

Author Contributions: All authors have contributed for development of this review paper and the order of authorship reflects their relative contribution. The original draft preparation was carried out by A.G., S.M.H., A.D.M.

Funding: This work has been supported by the Filling the Research Gap program funded by The Australian Government's Department of Agriculture and Water Resources, Meat and Livestock Australia, and Australian Wool Innovation. BC3 research is supported by the Basque Government through the BERC 2018-2021 program and by Spanish Ministry of Economy and Competitiveness MINECO through BC3 María de Maeztu excellence accreditation MDM-2017-0714.

Acknowledgments: We acknowledge Cesar Pinares Patino, Jeff Baldock, and Andrew Ash of CSIRO for their valuable comments. The authors acknowledge useful comments made by anonymous reviewers.

Conflicts of Interest: The authors declare no conflict of interest. 


\section{References}

1. FAO. Brief Analysis of FAO Statistical Data on Pasture and Fodder Crops. Available online: http://www.fao. org/uploads/media/grass_stats_1.pdf (accessed on 11 December 2019).

2. Herrero, M.; Havlik, P.; Valin, H.; Notenbaert, A.; Rufino, M.C.; Thornton, P.K.; Blummel, M.; Weiss, F.; Grace, D.; Obersteiner, M. Biomass use, production, feed efficiencies, and greenhouse gas emissions from global livestock systems. Proc. Natl. Acad. Sci. USA 2013, 110, 20888-20893. [CrossRef] [PubMed]

3. FAO. The State of Food and Agriculture: Livestock in the Balance; FAO: Rome, Italy, 2009.

4. Vermeulen, S.J.; Campbell, B.; Ingram, J.S. Climate Change and Food Systems. Annu. Rev. 2012, 37, $195-222$. [CrossRef]

5. IPCC. Climate Change 2014: Synthesis Report. Contribution of Working Groups I, II and III to the Fifth Assessment Report of the Intergovernmental Panel on Climate Change; Pachauri, R.K., Meyer, L.A., Eds.; IPCC: Geneva, Switzerland, 2014; p. 151.

6. Durack, P.J.; Wijffels, S.E.; Matear, R.J. Ocean salinities reveal strong global water cycle intensification during 1950 to 2000. Science 2012, 336, 455-458. [CrossRef] [PubMed]

7. IPCC. Climate Change 2014: Impacts, Adaptation, and Vulnerability. Part B: Regional Aspects. Contribution of Working Group II to the Fifth Assessment Report of the Intergovernmental Panel on Climate Change; Barros, V.R., Field, C.B., Dokken, D.J., Mastrandrea, M.D., Mach, K.J., Bilir, T.E., Chatterjee, M., Ebi, K.L., Estrada, Y.O., Genova, R.C., et al., Eds.; Cambridge University Press: Cambridge, UK; New York, NY, USA, 2014; p. 688.

8. Porter, J.R.; Xie, L.; Challinor, A.J.; Cochrane, K.; Howden, S.M.; Iqbal, M.M.; Lobell, D.B.; Travasso, M.I. Food security and food production systems. In Climate Change 2014: Impacts, Adaptation, and Vulnerability. Part A: Global and Sectoral Aspects. Contribution of Working Group II to the Fifth Assessment Report of the Intergovernmental Panel on Climate Change; Field, C.B., Barros, V.R., Dokken, D.J., Mach, K.J., Mastrandrea, M.D., Bilir, T.E., Chatterjee, M., Ebi, K.L., Estrada, Y.O., Genova, R.C., et al., Eds.; Cambridge University Press: Cambridge, UK; New York, NY, USA, 2014; pp. 485-533.

9. Rivera-Ferre, M.G.; López-i-Gelats, F.; Howden, M.; Smith, P.; Morton, J.F.; Herrero, M. Re-framing the climate change debate in the livestock sector: Mitigation and adaptation options. Wiley Interdiscip. Rev. Clim. Chang. 2016, 7, 869-892. [CrossRef]

10. Moore, A.D.; Ghahramani, A. Climate change and broadacre livestock production across southern Australia. 1. Impacts of climate change on pasture and livestock productivity, and on sustainable levels of profitability. Glob. Chang. Biol. 2013, 19, 1440-1455. [CrossRef] [PubMed]

11. Godber, O.F.; Wall, R. Mediterranean goat production systems: Vulnerability to population growth and climate change. Mediterr. J. Biosci. 2016, 1, 160-168.

12. Porqueddu, C.; Ates, S.; Louhaichi, M.; Kyriazopoulos, A.P.; Moreno, G.; Del Pozo, A.; Ovalle, C.; Ewing, M.A.; Nichols, P.G.H. Grasslands in 'Old World' and 'New World' Mediterranean-climate zones: Past trends, current status and future research priorities. Grass Forage Sci. 2016, 71, 1-35. [CrossRef]

13. Tubiello, F.N.; Soussana, J.F.; Howden, S.M. Crop and pasture response to climate change. Proc. Natl. Acad. Sci. USA 2007, 104, 19686-19690. [CrossRef]

14. Roy, J.; Picon-Cochard, C.; Augusti, A.; Benot, M.L.; Thiery, L.; Darsonville, O.; Landais, D.; Piel, C.; Defossez, M.; Devidal, S.; et al. Elevated $\mathrm{CO}_{2}$ maintains grassland net carbon uptake under a future heat and drought extreme. Proc. Natl. Acad. Sci. USA 2016, 113, 6224-6229. [CrossRef]

15. Soussana, J.F.; Tallec, T.; Blanfort, V. Mitigating the greenhouse gas balance of ruminant production systems through carbon sequestration in grasslands. Animal 2010, 4, 334-350. [CrossRef]

16. Myers, S.S.; Zanobetti, A.; Kloog, I.; Huybers, P.; Leakey, A.D.; Bloom, A.J.; Carlisle, E.; Dietterich, L.H.; Fitzgerald, G.; Hasegawa, T.; et al. Increasing $\mathrm{CO}_{2}$ threatens human nutrition. Nature 2014, 510, 139-142. [CrossRef] [PubMed]

17. Luo, Y.; Su, B.O.; Currie, W.S.; Dukes, J.S.; Finzi, A.; Hartwig, U.; Hungate, B.; McMurtrie, R.E.; Oren, R.A.M.; Parton, W.J.; et al. Progressive nitrogen limitation of ecosystem responses to rising atmospheric carbon dioxide. AIBS Bull. 2004, 54, 731-739. [CrossRef]

18. Reisinger, A.; Clark, H. How much do direct livestock emissions actually contribute to global warming? Glob. Chang. Biol. 2018, 24, 1749-1761. [CrossRef] [PubMed] 
19. Gerber, P.J.; Hristov, A.N.; Henderson, B.; Makkar, H.; Oh, J.; Lee, C.; Meinen, R.; Montes, F.; Ott, T.; Firkins, J.; et al. Technical options for the mitigation of direct methane and nitrous oxide emissions from livestock: A review. Animal 2013, 7, 220-234. [CrossRef]

20. Soussana, J.F.; Graux, A.I.; Tubiello, F.N. Improving the use of modelling for projections of climate change impacts on crops and pastures. J. Exp. Bot. 2010, 61, 2217-2228. [CrossRef]

21. Rigueiro-Rodríguez, A.; Fernández-Núñez, E.; González-Hernández, P.; McAdam, J.H.; Mosquera-Losada, M.R. Agroforestry Systems in Europe: Productive, Ecological and Social Perspectives. In Agroforestry in Europe; Springer: Berlin/Heidelberg, Germany, 2009; pp. 43-65.

22. Steinfeld, H.; Gerber, P.; Wassenaar, T.; Castel, V.; Rosales, M.; De Haan, C. Livestock's Long Shadow; FAO: Rome, Italy, 2006; p. 392.

23. Del Prado, A.; Crosson, P.; Olesen, J.E.; Rotz, C.A. Whole-farm models to quantify greenhouse gas emissions and their potential use for linking climate change mitigation and adaptation in temperate grassland ruminant-based farming systems. Animal 2013, 7, 373-385. [CrossRef]

24. Lüscher, A.; Mueller-Harvey, I.; Soussana, J.F.; Rees, R.M.; Peyraud, J.L. Potential of legume-based grassland-livestock systems in Europe: A review. Grass Forage Sci. 2014, 69, 206-228. [CrossRef]

25. Soussana, J.F.; Lüscher, A. Temperate grasslands and global atmospheric change: A review. Grass Forage Sci. 2007, 62, 127-134. [CrossRef]

26. Heskel, M.A.; O’Sullivan, O.S.; Reich, P.B.; Tjoelker, M.G.; Weerasinghe, L.K.; Penillard, A.; Egerton, J.J.G.; Creek, D.; Bloomfield, K.J.; Xiang, J.; et al. Convergence in the temperature response of leaf respiration across biomes and plant functional types. Proc. Natl. Acad. Sci. USA 2016, 113, 3832-3837. [CrossRef]

27. Lüscher, A.; Daepp, M.; Blum, H.; Hartwig, U.A.; Nösberger, J. Fertile temperate grassland under elevated atmospheric $\mathrm{CO}_{2}$-Role of feed-back mechanisms and availability of growth resources. Eur. J. Agron. 2004, 21, 379-398. [CrossRef]

28. DaMatta, F.M.; Grandis, A.; Arenque, B.C.; Buckeridge, M.S. Impacts of climate changes on crop physiology and food quality. Food Res. Int. 2010, 43, 1814-1823. [CrossRef]

29. Bolger, T.P.; Lilley, J.M.; Gifford, R.M.; Donnelly, J.R. Growth Response of Australian Temperate Pasture Species to $\mathrm{CO}_{2}$ Enrichment. In Proceedings of the 18th International Grassland Congress, Winnipeg, SK, Canada, 8-19 June 1997.

30. Morgan, J.A.; Pataki, D.E.; Körner, C.; Clark, H.; Del Grosso, S.J.; Grünzweig, J.M.; Knapp, A.K.; Mosier, A.R.; Newton, P.C.D.; Niklaus, P.A.; et al. Water relations in grassland and desert ecosystems exposed to elevated atmospheric $\mathrm{CO}_{2}$. Oecologia 2004, 140, 11-25. [CrossRef] [PubMed]

31. Rütting, T.; Clough, T.J.; Müller, C.; Lieffering, M.; Newton, P.C.D. Ten years of elevated atmospheric carbon dioxide alters soil nitrogen transformations in a sheep-grazed pasture. Glob. Chang. Biol. 2010, 16, 2530-2542. [CrossRef]

32. Nowak, R.S.; Ellsworth, D.S.; Smith, S.D. Functional responses of plants to elevated atmospheric $\mathrm{CO}_{2}-\mathrm{Do}$ photosynthetic and productivity data from FACE experiments support early predictions? New Phytol. 2004, 162, 253-280. [CrossRef]

33. Newton, P.C.D.; Allard, V.; Carran, R.A.; Lieffering, M. Impacts of Elevated $\mathrm{CO}_{2}$ on a Grassland Grazed by Sheep: The New Zealand FACE Experiment. In Managed Ecosystems and $\mathrm{CO}_{2}$; Springer: Berlin/Heidelberg, Germany, 2006; pp. 157-171.

34. Newton, P.C.D.; Lieffering, M.; Bowatte, W.M.S.D.; Brock, S.C.; Hunt, C.L.; Theobald, P.W.; Ross, D.J. The rate of progression and stability of progressive nitrogen limitation at elevated atmospheric $\mathrm{CO}_{2}$ in a grazed grassland over 11 years of Free Air $\mathrm{CO}_{2}$ enrichment. Plant Soil. 2010, 336, 433-441. [CrossRef]

35. Ledgard, S.F. Nitrogen cycling in low input legume-based agriculture, with emphasis on legume/grass pastures. Plant Soil 2001, 228, 43-59. [CrossRef]

36. Unkovich, M.; Sanford, P.; Pate, J.; Hyder, M. Effects of grazing on plant and soil nitrogen relations of pasture-crop rotations. Aust. J. Agric. Res. 1998, 49, 475-486. [CrossRef]

37. Parsons, A.J.; Orr, R.J.; Penning, P.D.; Rydein, J.C.; Lockyer, D.R. Uptake, cycling and fate of nitrogen in grass-Clover swards continuously grazed by sheep. J. Agric. Sci. 1991, 116, 47-61. [CrossRef]

38. Thomas, D.T.; Milton, J.T.B.; Revell, C.K.; Ewing, M.A.; Dynes, R.A.; Murray, K.; Lindsay, D.R. Preference of sheep among annual legumes is more closely related to plant nutritive characteristics as plants mature. Anim. Prod. Sci. 2010, 50, 114-123. [CrossRef] 
39. Polley, H.W.; Bailey, D.W.; Nowak, R.S.; Stafford-Smith, M. Ecological Consequences of Climate Change on Rangelands. In Rangeland Systems; Springer: Berlin/Heidelberg, Germany, 2017; pp. 229-260.

40. Barbehenn, R.V.; Chen, Z.; Karowe, D.N.; Spickard, A. C3grasses have higher nutritional quality than C4grasses under ambient and elevated atmospheric $\mathrm{CO}_{2}$. Glob. Chang. Biol. 2004, 10, 1565-1575. [CrossRef]

41. Campbell, B.D.; Stafford Smith, D.M. A synthesis of recent global change research on pasture and rangeland production: Reduced uncertainties and their management implications. Agric. Ecosyst. Environ. 2000, 82, 39-55. [CrossRef]

42. Schenk, U.; Manderscheid, R.; Hugen, J.; Weigel, H.J. Effects of $\mathrm{CO}_{2}$ enrichment and intraspecific competition on biomass partitioning, nitrogen content and microbial biomass carbon in soil of perennial ryegrass and white clover. J. Exp. Bot. 1995, 46, 987-993. [CrossRef]

43. Newton, P.C.D.; Lieffering, M.; Parsons, A.J.; Brock, S.C.; Theobald, P.W.; Hunt, C.L.; Luo, D.; Hovenden, M.J. Selective grazing modifies previously anticipated responses of plant community composition to elevated $\mathrm{CO}_{2}$ in a temperate grassland. Glob. Chang. Biol. 2014, 20, 158-169. [CrossRef] [PubMed]

44. Rutter, S.M. Diet preference for grass and legumes in free-ranging domestic sheep and cattle: Current theory and future application. Appl. Anim. Behav. Sci. 2006, 97, 17-35. [CrossRef]

45. Cantarel, A.A.M.; Bloor, J.M.G.; Soussana, J.F. Four years of simulated climate change reduces above-ground productivity and alters functional diversity in a grassland ecosystem. J. Veg. Sci. 2013, 24, 113-126. [CrossRef]

46. Hovenden, M.J.; Miglietta, F.; Zaldei, A.; Vander Schoor, J.K.; Wills, K.E.; Newton, P.C.D. The TasFACE climate-change impacts experiment: Design and performance of combined elevated $\mathrm{CO} 2$ and temperature enhancement in a native Tasmanian grassland. Aust. J. Bot. 2006, 54, 1-10. [CrossRef]

47. Hovenden, M.J.; Newton, P.C.D.; Wills, K.E. Seasonal not annual rainfall determines grassland biomass response to carbon dioxide. Nature 2014, 511, 583. [CrossRef]

48. Parton, W.J.; Scurlock, J.M.O.; Ojima, D.S.; Schimel, D.S.; Hall, D.O. Impact of climate change on grassland production and soil carbon worldwide. Glob. Chang. Biol. 1995, 1, 13-22. [CrossRef]

49. Rounsevell, M.D.A.; Brignall, A.P.; Siddons, P.A. Potential climate change effects on the distribution of agricultural grassland in England and Wales. Soil Use Manag. 1996, 12, 44-51. [CrossRef]

50. Riedo, M.; Gyalistras, D.; Fischlin, A.; Fuhrer, J. Using an ecosystem model linked to GCM-derived local weather scenarios to analyse effects of climate change and elevated $\mathrm{CO}_{2}$ on dry matter production and partitioning, and water use in temperate managed grasslands. Glob. Chang. Biol. 1999, 5, 213-223. [CrossRef]

51. Morales, P.; Hickler, T.; Rowell, D.P.; Smith, B.; Sykes, M.T. Changes in European ecosystem productivity and carbon balance driven by regional climate model output. Glob. Chang. Biol. 2007, 13, 108-122. [CrossRef]

52. Thomson, A.M.; Brown, R.A.; Rosenberg, N.J.; Izaurralde, R.C.; Benson, V. Climate Change Impacts for the Conterminous USA, Climate Change Impacts for the Conterminous USA: An Integrated Assessment. Clim. Chang. 2005, 69, 67-88. [CrossRef]

53. Rotz, C.A.; Corson, M.S.; Chianese, D.S.; Montes, F.; Hafner, S.D.; Coiner, C.U. The Integrated Farm System Model. Available online: https://www.ars.usda.gov/northeast-area/up-pa/pswmru/docs/integrated-farmsystem-model (accessed on 11 December 2019).

54. Thivierge, M.N.; Jégo, G.; Bélanger, G.; Bertrand, A.; Tremblay, G.F.; Rotz, C.A.; Qian, B. Predicted yield and nutritive value of an alfalfa-timothy mixture under climate change and elevated atmospheric carbon dioxide. Agron. J. 2016, 108, 585-603. [CrossRef]

55. Cullen, B.R.; Johnson, I.R.; Eckard, R.J.; Lodge, G.M.; Walker, R.G.; Rawnsley, R.P.; McCaskill, M.R. Climate change effects on pasture systems in south-eastern Australia. Crop. Pasture Sci. 2009, 60, 933-942. [CrossRef]

56. Belgacem, A.O.; Louhaichi, M. The vulnerability of native rangeland plant species to global climate change in the West Asia and North African regions. Clim. Chang. 2013, 119, 451-463. [CrossRef]

57. Murphy, K.L.; Burke, I.C.; Vinton, M.A.; Lauenroth, W.K.; Aguiar, M.R.; Wedin, D.A.; Virginia, R.A.; Lowe, P.N. Regional analysis of litter quality in the central grassland region of North America. J. Veg. Sci. 2002, 13, 395-402. [CrossRef]

58. Phelan, P.; Morgan, E.R.; Rose, H.; Grant, J.; O'Kiely, P. Predictions of future grazing season length for European dairy, beef and sheep farms based on regression with bioclimatic variables. J. Agric. Sci. 2016, 154, 765-781. [CrossRef]

59. Moore, A.D.; Ghahramani, A. Estimated Effects of Climate Change on Grassland Production and Legume Content Across Southern Australia. In Proceedings of the 22nd International Grassland Congress, Sydney, 
Australia, 15-19 September 2013; New South Wales Department of Primary Industry: Sydney, Australia, 2013; pp. 1309-1310.

60. Webb, N.P.; Stokes, C.J.; Scanlan, J.C. Interacting effects of vegetation, soils and management on the sensitivity of Australian savanna rangelands to climate change. Clim. Chang. 2012, 112, 925-943. [CrossRef]

61. Juin, S.; Brisson, N.; Clastre, P.; Grand, P. Impact of global warming on the growing cycles of three forage systems in upland areas of southeastern France. Agronomie 2004, 24, 327-337. [CrossRef]

62. Perring, M.P.; Cullen, B.R.; Johnson, I.R.; Hovenden, M.J. Modelled effects of rising $\mathrm{CO}_{2}$ concentration and climate change on native perennial grass and sown grass-legume pastures. Clim. Res. 2010, 42, 65-78. [CrossRef]

63. Graux, A.I.; Gaurut, M.; Agabriel, J.; Baumont, R.; Delagarde, R.; Delaby, L.; Soussana, J.F. Development of the pasture simulation model for assessing livestock production under climate change. Agric. Ecosyst. Environ. 2011, 144, 69-91. [CrossRef]

64. Yang, H.; Wu, M.; Liu, W.; Zhang, Z.; Zhang, N.; Wan, S. Community structure and composition in response to climate change in a temperate steppe. Glob. Chang. Biol. 2011, 17, 452-465. [CrossRef]

65. Topp, C.F.E.; Doyle, C.J. Simulating the impact of global warming on milk and forage production in Scotland: 1. The effects on dry-matter yield of grass and grass-white clover swards. Agric. Syst. 1996, 52, $213-242$. [CrossRef]

66. Ghahramani, A.; Moore, A.D. Impact of climate changes on existing crop-livestock farming systems. Agric. Syst. 2016, 146, 142-155. [CrossRef]

67. Höglind, M.; Thorsen, S.M.; Semenov, M.A. Assessing uncertainties in impact of climate change on grass production in Northern Europe using ensembles of global climate models. Agric. For. Meteorol. 2013, 170, 103-113. [CrossRef]

68. Rapacz, M.; Ergon, Å.; Höglind, M.; Jørgensen, M.; Jurczyk, B.; Østrem, L.; Rognli, O.A.; Tronsmo, A.M. Overwintering of herbaceous plants in a changing climate. Still more questions than answers. Plant Sci. 2014, 225, 34-44. [CrossRef]

69. Cordeiro, M.R.; Rotz, A.; Kroebel, R.; Beauchemin, K.A.; Hunt, D.; Bittman, S.; Koenig, K.M.; McKenzie, D.B. Prospects of Forage Production in Northern Regions under Climate and Land-Use Changes: A Case-Study of a Dairy Farm in Newfoundland, Canada. Agronomy 2019, 9, 31. [CrossRef]

70. Craine, J.M.; Elmore, A.J.; Olson, K.C.; Tolleson, D. Climate change and cattle nutritional stress. Glob. Chang. Biol. 2010, 16, 2901-2911. [CrossRef]

71. Izaurralde, R.C.; Thomson, A.M.; Morgan, J.A.; Fay, P.A.; Polley, H.W.; Hatfield, J.L. Climate impacts on agriculture: Implications for forage and rangeland production. Agron. J. 2011, 103, 371-381. [CrossRef]

72. Theurillat, J.P.; Guisan, A. Potential impact of climate change on vegetation in the European alps: A review. Clim. Chang. 2001, 50, 77-109. [CrossRef]

73. Dumont, B.; Andueza, D.; Niderkorn, V.; Lüscher, A.; Porqueddu, C.; Picon-Cochard, C. A meta-analysis of climate change effects on forage quality in grasslands: Specificities of mountain and Mediterranean areas. Grass Forage Sci. 2015, 70, 239-254. [CrossRef]

74. Purser, D.B. The nutritional value of stubbles. In Proceedings of the Stubble utilisation: Proceedings of a Seminar, Perth, WA, Australia, 28 October 1983; pp. 13-26.

75. Kipling, R.P.; Bannink, A.; Bellocchi, G.; Dalgaard, T.; Fox, N.J.; Hutchings, N.J.; Kjeldsen, C.; Lacetera, N.; Sinabell, F.; Topp, C.F.E.; et al. Modeling European ruminant production systems: Facing the challenges of climate change. Agric. Syst. 2016, 147, 24-37. [CrossRef]

76. Kipling, R.P.; Virkajärvi, P.; Breitsameter, L.; Curnel, Y.; De Swaef, T.; Gustavsson, A.M.; Hennart, S.; Höglind, M.; Järvenranta, K.; Minet, J.; et al. Key challenges and priorities for modelling European grasslands under climate change. Sci. Total Environ. 2016, 566, 851-864. [CrossRef] [PubMed]

77. Claessens, L.; Antle, J.M.; Stoorvogel, J.J.; Valdivia, R.O.; Thornton, P.K.; Herrero, M. A method for evaluating climate change adaptation strategies for small-scale farmers using survey, experimental and modeled data. Agric. Syst. 2012, 111, 85-95. [CrossRef]

78. Özkan, Ş.; Vitali, A.; Lacetera, N.; Amon, B.; Bannink, A.; Bartley, D.J.; Blanco-Penedo, I.; de Haas, Y.; Dufrasne, I.; Elliott, J.; et al. Challenges and priorities for modelling livestock health and pathogens in the context of climate change. Environ. Res. 2016, 151, 130-144. [CrossRef]

79. Renaudeau, D.; Gourdine, J.L.; St-Pierre, N.R. Meta-analysis of the effects of high ambient temperature on growth performance of growing-finishing pigs. J. Anim. Sci. 2011, 89, 2220-2230. [CrossRef] 
80. Nardone, A.; Ronchi, B.; Lacetera, N.; Ranieri, M.S.; Bernabucci, U. Effects of climate changes on animal production and sustainability of livestock systems. Livest. Sci. 2010, 130, 57-69. [CrossRef]

81. IPCC. Climate Change 2007: The Physical Science Basis. Contribution of Working Group I to the Fourth Assessment Report of the Intergovernmental Panel on Climate Change; Solomon, S., Qin, D., Manning, M., Chen, Z., Marquis, M., Averyt, K.B., Tignor, M., Miller, H.L., Eds.; Cambridge University Press: Cambridge, UK; New York, NY, USA, 2007; p. 996.

82. Lamy, E.; Van Harten, S.; Sales-Baptista, E.; Guerra, M.M.M.; De Almeida, A.M. Factors Influencing Livestock Productivity. In Environmental Stress and Amelioration in Livestock Production; Springer: Berlin/Heidelberg, Germany, 2012; pp. 19-51. [CrossRef]

83. Nienaber, J.A.; Hahn, G.L. Livestock production system management responses to thermal challenges. Int. J. Biometeorol. 2007, 52, 149-157. [CrossRef]

84. Guis, H.; Caminade, C.; Calvete, C.; Morse, A.P.; Tran, A.; Baylis, M. Modelling the effects of past and future climate on the risk of bluetongue emergence in Europe. J. R. Soc. Interface 2012, 9, 339-350. [CrossRef]

85. Sevi, A.; Annicchiarico, G.; Albenzio, M.; Taibi, L.; Muscio, A.; Dell'Aquila, S. Effects of Solar Radiation and Feeding Time on Behavior, Immune Response and Production of Lactating Ewes Under High Ambient Temperature. J. Dairy Sci. 2001, 84, 629-640. [CrossRef]

86. Silanikove, N. Effects of water scarcity and hot environment on appetite and digestion in ruminants: A review. Livest. Prod. Sci. 1992, 30, 175-194. [CrossRef]

87. Sevi, A.; Caroprese, M. Impact of heat stress on milk production, immunity and udder health in sheep: A critical review. Small Rumin. Res. 2012, 107, 1-7. [CrossRef]

88. Bernabucci, U.; Lacetera, N.; Danieli, P.P.; Bani, P.; Nardone, A.; Ronchi, B. Influence of different periods of exposure to hot environment on rumen function and diet digestibility in sheep. Int. J. Biometeorol. 2009, 53, 387-395. [CrossRef] [PubMed]

89. Thomas, D.T.; Wilmot, M.G.; Alchin, M.; Masters, D.G. Preliminary indications that Merino sheep graze different areas on cooler days in the Southern Rangelands of Western Australia. Aust. J. Exp. Agric. 2008, 48, 889-892. [CrossRef]

90. Sevi, A.; Rotunno, T.; Di Caterina, R.; Muscio, A. Fatty acid composition of ewe milk as affected by solar radiation and high ambient temperature. J. Dairy Res. 2002, 69, 181-194. [CrossRef] [PubMed]

91. Marino, R.; Atzori, A.S.; D’Andrea, M.; Iovane, G.; Trabalza-Marinucci, M.; Rinaldi, L. Climate change: Production performance, health issues, greenhouse gas emissions and mitigation strategies in sheep and goat farming. Small Rumin. Res. 2016, 135, 50-59. [CrossRef]

92. Thornton, P.K.; van de Steeg, J.; Notenbaert, A.; Herrero, M. The impacts of climate change on livestock and livestock systems in developing countries: A review of what we know and what we need to know. Agric. Syst. 2009, 101, 113-127. [CrossRef]

93. Jolly, S.; Ann, W. Best Practice for Production Feeding of Lambs: A Review of the Literature; Meat \& Livestock Australia Limited: Sydney, Australia, 2016.

94. McCrabb, G.J.; McDonald, B.J.; Hennoste, L.M. Heat stress during mid-pregnancy in sheep and the consequences for placental and fetal growth. J. Agric. Sci. 1993, 120, 265-271. [CrossRef]

95. Amundson, J.L.; Mader, T.L.; Rasby, R.J.; Hu, Q.S. Environmental effects on pregnancy rate in beef cattle. J. Anim. Sci. 2006, 84, 3415-3420. [CrossRef]

96. Rickards, L.; Howden, S.M. Transformational adaptation: Agriculture and climate change. Crop. Pasture Sci. 2012, 63, 240-250. [CrossRef]

97. Moore, A.D.; Ghahramani, A. Climate change and broadacre livestock production across southern Australia. 3. Adaptation options via livestock genetic improvement. Anim. Prod. Sci. 2014, 54, 111-124. [CrossRef]

98. Das, R.; Sailo, L.; Verma, N.; Bharti, P.; Saikia, J.; Imtiwati; Kumar, R. Impact of heat stress on health and performance of dairy animals: A review. Vet. World 2016, 9, 260. [CrossRef] [PubMed]

99. Caroprese, M.; Albenzio, M.; Bruno, A.; Fedele, V.; Santillo, A.; Sevi, A. Effect of solar radiation and flaxseed supplementation on milk production and fatty acid profile of lactating ewes under high ambient temperature. J. Dairy Sci. 2011, 94, 3856-3867. [CrossRef] [PubMed]

100. Blackshaw, J.K.; Blackshaw, A.W. Heat stress in cattle and the effect of shade on production and behaviour: A review. Aust. J. Exp. Agric. 1994, 34, 285-295. [CrossRef]

101. Silanikove, N. Effects of heat stress on the welfare of extensively managed domestic ruminants. Livest. Prod. Sci. 2000, 67, 1-18. [CrossRef] 
102. Coates, D.B.; Mannetje, L.; Seifert, G.W. Reproductive performance and calf growth to weaning of hereford and belmont red cattle in subtropical, subcoastal queensland. Aust. J. Exp. Agric. 1987, 27, 1-10. [CrossRef]

103. Kilminster, T.F.; Greeff, J.C. A note on the reproductive performance of Damara, Dorper and Merino sheep under optimum management and nutrition for Merino ewes in the eastern wheatbelt of Western Australia. Trop. Anim. Health Prod. 2011, 43, 1459-1464. [CrossRef]

104. Ghahramani, A.; Moore, A.D. Climate change and broadacre livestock production across southern Australia. 2. Adaptation options via grassland management. Crop. Pasture Sci. 2013, 64, 615-630. [CrossRef]

105. Macleod, C.J.A.; Humphreys, M.W.; Whalley, W.R.; Turner, L.; Binley, A.; Watts, C.W.; Skøt, L.; Joynes, A.; Hawkins, S.; King, I.P.; et al. A novel grass hybrid to reduce flood generation in temperate regions. Sci. Rep. 2013, 3, 1683. [CrossRef]

106. Humphreys, M.W.; O’Donovan, S.A.; Farrell, M.S.; Gay, A.P.; Kingston-Smith, A.H. The potential of novel Festulolium $(2 \mathrm{n}=4 \mathrm{x}=28)$ hybrids as productive, nutrient- use- efficient fodder for ruminants. Food Energy Secur. 2014, 3, 98-110. [CrossRef]

107. Volaire, F.; Barkaoui, K.; Norton, M. Designing resilient and sustainable grasslands for a drier future: Adaptive strategies, functional traits and biotic interactions. Eur. J. Agron. 2014, 52, 81-89. [CrossRef]

108. Cowles, J.M.; Wragg, P.D.; Wright, A.J.; Powers, J.S.; Tilman, D. Shifting grassland plant community structure drives positive interactive effects of warming and diversity on aboveground net primary productivity. Glob. Chang. Biol. 2016, 22, 741-749. [CrossRef] [PubMed]

109. Wright, A.J.; de Kroon, H.; Visser, E.J.W.; Buchmann, T.; Ebeling, A.; Eisenhauer, N.; Fischer, C.; Hildebrandt, A.; Ravenek, J.; Roscher, C.; et al. Plants are less negatively affected by flooding when growing in species-rich plant communities. New Phytol. 2017, 213, 645-656. [CrossRef] [PubMed]

110. Waghorn, G.C.; Hegarty, R.S. Lowering ruminant methane emissions through improved feed conversion efficiency. Anim. Feed Sci. Technol. 2011, 166, 291-301. [CrossRef]

111. Ghahramani, A.; Bowran, D. Transformative and systemic climate change adaptations in mixed crop-livestock farming systems. Agric. Syst. 2018, 164, 236-251. [CrossRef]

112. Waghorn, G.C.; McNabb, W.C. Consequences of plant phenolic compounds for productivity and health of ruminants. Proc. Nutr. Soc. 2003, 62, 383-392. [CrossRef]

113. Rinne, M.; Dragomir, C.; Kuoppala, K.; Marley, C.; Smith, J.; Yanez Ruiz, D. Novel and underutilized feed resources-potential for use in organic and low input dairy production. Agric. For. Res. 2012, 362, 404-407.

114. Pardo, G.; Martin-Garcia, I.; Arco, A.; Yañez-Ruiz, D.R.; Moral, R.; Del Prado, A. Greenhouse-gas mitigation potential of agro-industrial by-products in the diet of dairy goats in Spain: A life-cycle perspective. Anim. Prod. Sci. 2016, 56, 646-654. [CrossRef]

115. Arco-Pérez, A.; Ramos-Morales, E.; Yáñez-Ruiz, D.R.; Abecia, L.; Martín-García, A.I. Nutritive evaluation and milk quality of including of tomato or olive by-products silages with sunflower oil in the diet of dairy goats. Anim. Feed. Sci. Technol. 2017, 232, 57-70. [CrossRef]

116. Ghahramani, A.; Moore, A.D. Systemic adaptations to climate change in southern Australian grasslands and livestock: Production, profitability, methane emission and ecosystem function. Agric. Syst. 2015, 133, 158-166. [CrossRef]

117. Kenyon, F.; Dick, J.; Smith, R.; Coulter, D.; McBean, D.; Skuce, P. Reduction in Greenhouse Gas Emissions Associated with Worm Control in Lambs. Agriculture 2013, 3, 271-284. [CrossRef]

118. Craine, J.M.; Ocheltree, T.W.; Nippert, J.B.; Towne, E.G.; Skibbe, A.M.; Kembel, S.W.; Fargione, J.E. Global diversity of drought tolerance and grassland climate-change resilience. Nat. Clim. Chang. 2013, 3, 63. [CrossRef]

119. Ghelichkhan, M.; Eun, J.S.; Christensen, R.G.; Stott, R.D.; MacAdam, J.W. Urine volume and nitrogen excretion are altered by feeding birdsfoot trefoil compared with alfalfa in lactating dairy cows. J. Anim. Sci. 2018, 96, 3993-4001. [CrossRef] [PubMed]

120. Totty, V.K.; Greenwood, S.L.; Bryant, R.H.; Edwards, G.R. Nitrogen partitioning and milk production of dairy cows grazing simple and diverse pastures. J. Dairy Sci. 2013, 96, 41-149. [CrossRef] [PubMed]

121. Adeh, E.H.; Selker, J.S.; Higgins, C.W. Remarkable agrivoltaic influence on soil moisture, micrometeorology and water-use efficiency. PLOS ONE 2018, 13, e0203256.

122. Stephenson, R.G.A.; Suter, G.R.; Le Feuvre, A.S. Reduction of the Effects of Heat Stress on Lamb Birth Weight and Survival by Provision of Shade. In Reproduction in Sheep; Lindsay, D.R., Pearce, D.T., Eds.; Cambridge University Press: Cambridge, UK, 1984. 
123. Hoffmann, I. Climate change and the characterization, breeding and conservation of animal genetic resources. Anim. Genet. 2010, 41, 32-46. [CrossRef]

124. Keating, B.A.; Carberry, P.S.; Bindraban, P.S.; Asseng, S.; Meinke, H.; Dixon, J. Eco-efficient agriculture: Concepts, Challenges, and opportunities. Crop Sci. 2010, 50 (Suppl. 1), S109-S119. [CrossRef]

125. Ghahramani, A.; Moore, A.D. Climate Change Impact and Adaptation in Temperate Grassland and Livestock Industries. In Proceedings of the 23rd International Grassland Congress: Keynote Lectures, New Delhi, India, 20-24 November 2015; IGC: New Delhi, India, 2015; pp. 349-360.

126. Kabubo-Mariara, J. Global warming and livestock husbandry in Kenya: Impacts and adaptations. Ecol. Econ. 2009, 68, 1915-1924. [CrossRef]

127. Bell, L.W.; Moore, A.D. Integrated crop-livestock systems in Australian agriculture: Trends, drivers and implications. Agric. Syst. 2012, 111,1-12. [CrossRef]

128. Ghahramani, A.; Kingwell, R.S.; Maraseni, T.N. Land use change in Australian mixed crop-livestock systems as a transformative climate change adaptation. Agric. Syst. 2019. October 2019 Submitted.

129. Thamo, T.; Addai, D.; Pannell, D.J.; Robertson, M.J.; Thomas, D.T.; Young, J.M. Climate change impacts and farm-level adaptation: Economic analysis of a mixed cropping-livestock system. Agric. Syst. 2017, 150, 99-108. [CrossRef]

130. Thomas, D.T.; Moore, A.D.; Bell, L.W.; Webb, N.P. Ground cover, erosion risk and production implications of targeted management practices in Australian mixed farming systems: Lessons from the Grain and Graze program. Agric. Syst. 2018, 162, 123-135. [CrossRef]

131. Cheng, L.; McCormick, J.; Logan, C.; Hague, H.; Hodge, M.C.; Edwards, G.R. Liveweight gain and urinary nitrogen excretion of dairy heifers grazing perennial ryegrass-white clover pasture, canola, and wheat. Anim. Prod. Sci. 2018, 58, 1073-1078. [CrossRef]

132. Del Prado, A.; Chadwick, D.; Cardenas, L.; Misselbrook, T.; Scholefield, D.; Merino, P. Exploring systems responses to mitigation of GHG in UK dairy farms. Agric. Ecosyst. Environ. 2010, 136, 318-332. [CrossRef]

133. Grainger, C.; Clarke, T.; Auldist, M.J.; Beauchemin, K.A.; McGinn, S.M.; Waghorn, G.C.; Eckard, R.J. Potential use of Acacia mearnsii condensed tannins to reduce methane emissions and nitrogen excretion from grazing dairy cows. Can. J. Anim. Sci. 2009, 89, 241-251. [CrossRef]

134. Bell, M.J.; Eckard, R.J.; Cullen, B.R. The effect of future climate scenarios on the balance between productivity and greenhouse gas emissions from sheep grazing systems. Livest. Sci. 2012, 147, 126-138. [CrossRef]

135. Velthof, G.L.; Oudendag, D.; Witzke, H.P.; Asman, W.A.H.; Klimont, Z.; Oenema, O. Integrated Assessment of Nitrogen Losses from Agriculture in EU-27 using MITERRA-EUROPE. J. Environ. Q. 2009, 38, $402-417$. [CrossRef]

136. Chappell, A.; Webb, N.P.; Guerschman, J.P.; Thomas, D.T.; Mata, G.; Handcock, R.N.; Leys, J.F.; Butler, H.J. Improving ground cover monitoring for wind erosion assessment using MODIS BRDF parameters. Remote Sens. Environ. 2018, 204, 756-768. [CrossRef]

137. Lang, R.D.; McCaffrey, L.A.H. Ground cover-Its affects on soil loss from grazed runoff plots, Gunnedah. J. Soil Conserv. Available online: http://agris.fao.org/agris-search/search.do?recordID=US201302549302 (accessed on 12 December 2019).

138. Bolan, N.S.; Hedley, M.J.; White, R.E. Processes of soil acidification during nitrogen cycling with emphasis on legume based pastures. Plant Soil. 1991, 134, 53-63. [CrossRef]

139. Del Prado, A.; Mas, K.; Pardo, G.; Gallejones, P. Modelling the interactions between C and N farm balances and GHG emissions from confinement dairy farms in northern Spain. Sci. Total Environ. 2013, 465, 156-165. [CrossRef]

140. Pilgrim, E.S.; Macleod, C.J.A.; Blackwell, M.S.A.; Bol, R.; Hogan, D.V.; Chadwick, D.R.; Cardenas, L.; Misselbrook, T.H.; Haygarth, P.M.; Brazier, R.E.; et al. Interactions among agricultural production and other ecosystem services delivered from European temperate grassland systems. Adv. Agron. 2010, 109, 117-154. [CrossRef]

141. Lamarque, P.; Lavorel, S.; Mouchet, M.; Quétier, F. Plant trait-based models identify direct and indirect effects of climate change on bundles of grassland ecosystem services. Proc. Natl. Acad. Sci. USA 2014, 111, 13751-13756. [CrossRef] [PubMed]

142. Del Prado, A.; Scholefield, D. Use of SIMSDAIRY modelling framework system to compare the scope on the sustainability of a dairy farm of animal and plant genetic-based improvements with management-based changes. J. Agric. Sci. 2008, 146, 195-211. [CrossRef] 
143. Del Prado, A.; Misselbrook, T.; Chadwick, D.; Hopkins, A.; Dewhurst, R.J.; Davison, P.; Butler, A.; Schröder, J.; Scholefield, D. SIMSDAIRY: A modelling framework to identify sustainable dairy farms in the UK. Framework description and test for organic systems and N fertiliser optimisation. Sci. Total Environ. 2011, 409, 3993-4009. [CrossRef]

144. Thomas, D.T.; Sanderman, J.; Eady, S.J.; Masters, D.G.; Sanford, P. Whole farm net greenhouse gas abatement from establishing kikuyu-based perennial pastures in South-Western Australia. Animals 2012, 2, 316-330. [CrossRef]

145. O’Brien, D.; Shalloo, L.; Patton, J.; Buckley, F.; Grainger, C.; Wallace, M. Evaluation of the effect of accounting method, IPCC v. LCA, on grass-based and confinement dairy systems' greenhouse gas emissions. Animal 2012, 6, 1512-1527. [CrossRef]

146. Harrison, M.T.; Christie, K.M.; Rawnsley, R.P.; Eckard, R.J. Modelling pasture management and livestock genotype interventions to improve whole-farm productivity and reduce greenhouse gas emissions intensities. Anim. Prod. Sci. 2014, 54, 2018-2028. [CrossRef]

147. Zehetmeier, M.; Baudracco, J.; Hoffmann, H.; Heißenhuber, A. Does increasing milk yield per cow reduce greenhouse gas emissions? A system approach. Animal 2012, 6, 154-166. [CrossRef]

148. Moore, J.L.; Howden, S.M.; McKeon, G.M.; Carter, J.O.; Scanlan, J.C. The dynamics of grazed woodlands in southwest Queensland, Australia and their effect on greenhouse gas emissions. Environ. Int. 2001, 27, 147-153. [CrossRef]

149. Moore, A.D.; Holzworth, D.P.; Herrmann, N.I.; Brown, H.E.; de Voil, P.G.; Snow, V.O.; Zurcher, E.J.; Huth, N.I. Modelling the manager: Representing rule-based management in farming systems simulation models. Environ. Model. Softw. 2014, 62, 399-410. [CrossRef]

150. Lieffering, M.; Newton, P.C.D.; Vibart, R.; Li, F.Y. Exploring climate change impacts and adaptations of extensive pastoral agriculture systems by combining biophysical simulation and farm system models. Agric. Syst. 2016, 144, 77-86. [CrossRef]

151. Freer, M.; Moore, A.D.; Donnelly, J.R. GRAZPLAN: decision support systems for Australian grazing enterprises. II. The animal biology model for feed intake, production and reproduction and the GrazFeed DSS. Agric. Syst. 1997, 54, 77-126. [CrossRef]

152. Charmley, E.; Williams, S.R.O.; Moate, P.J.; Hegarty, R.S.; Herd, R.M.; Oddy, V.H.; Reyenga, P.; Staunton, K.M.; Anderson, A.; Hannah, M.C. A universal equation to predict methane production of forage-fed cattle in Australia. Anim. Prod. Sci. 2016, 56, 169-180. [CrossRef]

153. Hegarty, R.S. Reducing rumen methane emissions through elimination of rumen protozoa. Aust. J. Agric. Res. 1999, 50, 1321-1328. [CrossRef]

154. Grainger, C.; Beauchemin, K.A. Can enteric methane emissions from ruminants be lowered without lowering their production? Anim. Feed Sci. Technol. 2011, 166, 308-320. [CrossRef]

155. Hristov, A.N.; Oh, J.; Giallongo, F.; Frederick, T.W.; Harper, M.T.; Weeks, H.L.; Branco, A.F.; Moate, P.J.; Deighton, M.H.; Williams, S.R.O. An inhibitor persistently decreased enteric methane emission from dairy cows with no negative effect on milk production. Proc. Natl. Acad. Sci. USA 2015, 112, 10663-10668. [CrossRef]

156. Van Zijderveld, S.M.; Gerrits, W.J.J.; Dijkstra, J.; Newbold, J.R.; Hulshof, R.B.A.; Perdok, H.B. Persistency of methane mitigation by dietary nitrate supplementation in dairy cows. J. Dairy Sci. 2011, 94, 4028-4038. [CrossRef]

157. Banik, B.K.; Durmic, Z.; Erskine, W.; Ghamkhar, K.; Revell, C. In vitro ruminal fermentation characteristics and methane production differ in selected key pasture species in Australia. Crop. Pasture Sci. 2013, 64, 935-942. [CrossRef]

158. Durmic, Z.; Moate, P.J.; Eckard, R.; Revell, D.K.; Williams, R.; Vercoe, P.E. In vitro screening of selected feed additives, plant essential oils and plant extracts for rumen methane mitigation. J. Sci. Food Agric. 2014, 94, 1191-1196. [CrossRef]

159. Wedlock, D.N.; Janssen, P.H.; Leahy, S.C.; Shu, D.; Buddle, B.M. Progress in the development of vaccines against rumen methanogens. Animal 2013, 7, 244-252. [CrossRef]

160. Basarab, J.A.; Beauchemin, K.A.; Baron, V.S.; Ominski, K.H.; Guan, L.L.; Miller, S.P.; Crowley, J.J. Reducing GHG emissions through genetic improvement for feed efficiency: Effects on economically important traits and enteric methane production. Animal 2013, 7, 303-315. [CrossRef] [PubMed] 
161. Howden, S.M.; Reyenga, P.J. Methane emissions from Australian livestock: Implications of the Kyoto Protocol. Aust. J. Agric. Res. 1999, 50, 1285-1292. [CrossRef]

162. Henry, B.; Charmley, E.; Eckard, R.; Gaughan, J.B.; Hegarty, R. Livestock production in a changing climate: Adaptation and mitigation research in Australia. Crop. Pasture Sci. 2012, 63, 191-202. [CrossRef]

163. De Oliveira Silva, R.; Barioni, L.G.; Hall, J.A.J.; Folegatti Matsuura, M.; Zanett Albertini, T.; Fernandes, F.A.; Moran, D. Increasing beef production could lower greenhouse gas emissions in Brazil if decoupled from deforestation. Nat. Clim. Chang. 2016, 6, 493. [CrossRef]

164. Gerber, P.J.; Henderson, B.; Makkar, H.P. Mitigation of Greenhouse Gas Emissions in Livestock Production: A Review of Technical Options for Non-CO2 Emissions (No. 177); FAO: Rome, Italy, 2013.

165. Smith, P.; Olesen, J.E. Synergies between the mitigation of, and adaptation to, climate change in agriculture. J. Agric. Sci. 2010, 148, 543-552. [CrossRef]

166. Jarvis, A.; Lau, C.; Cook, S.; Wollenberg, E.; Hansen, J.; Bonilla, O.; Challinor, A. An integrated adaptation and mitigation framework for developing agricultural research: Synergies and trade-offs. Exp. Agric. 2011, 47, 185-203. [CrossRef]

167. DoE. Australia's Emissions Projections 2014-15; Department of the Environment: Canberra, Australia, 2015.

168. Howden, S.M.; Moore, J.L.; McKeon, G.M.; Carter, J.O. Global change and the mulga woodlands of southwest Queensland: Greenhouse gas emissions, impacts, and adaptation. Environ. Int. 2001, 27, 161-166. [CrossRef]

169. De Boer, I.J.M.; Cederberg, C.; Eady, S.; Gollnow, S.; Kristensen, T.; Macleod, M.; Meul, M.; Nemecek, T.; Phong, L.T.; Thoma, G.; et al. Greenhouse gas mitigation in animal production: Towards an integrated life cycle sustainability assessment. Curr. Opin. Environ. Sustain. 2011, 3, 423-431. [CrossRef]

170. Desjardins, R.L.; Smith, W.; Grant, B.; Campbell, C.; Riznek, R. Management Strategies to Sequester Carbon in Agricultural Soils and to Mitigate Greenhouse Gas Emissions. In Increasing Climate Variability and Change: Reducing the Vulnerability of Agriculture and Forestry; Springer: Berlin/Heidelberg, Germany, 2005; pp. $283-297$. [CrossRef]

171. Liebig, M.A.; Johnson, H.A.; Hanson, J.D.; Frank, A.B. Soil carbon under switchgrass stands and cultivated cropland. Biomass Bioenergy 2005, 28, 347-354. [CrossRef]

172. Yuan, Z.Q.; Yu, K.L.; Guan, X.K.; Fang, C.; Li, M.; Shi, X.Y.; Li, F.M. Medicago sativa improves soil carbon sequestration following revegetation of degraded arable land in a semi-arid environment on the Loess Plateau, China. Agric. Ecosyst. Environ. 2016, 232, 93-100. [CrossRef]

173. Cottle, D.J.; Harrison, M.T.; Ghahramani, A. Sheep greenhouse gas emission intensities under different management practices, climate zones and enterprise types. Anim. Prod. Sci. 2016, 56, 507-518. [CrossRef]

174. Verchot, L.V.; Van Noordwijk, M.; Kandji, S.; Tomich, T.; Ong, C.; Albrecht, A.; Mackensen, J.; Bantilan, C.; Anupama, K.V.; Palm, C. Climate change: linking adaptation and mitigation through agroforestry. Mitig. Adapt. Strat. Glob. Chang. 2007, 12, 901-918. [CrossRef]

175. Fraser, M.D.; Moorby, J.M.; Vale, J.E.; Evans, D.M. Mixed grazing systems benefit both upland biodiversity and livestock production. PLoS ONE 2014, 9, e89054. [CrossRef] [PubMed]

176. Thornton, P.K.; Herrero, M. Potential for reduced methane and carbon dioxide emissions from livestock and pasture management in the tropics. Proc. Natl. Acad. Sci. USA 2010, 107, 19667-19672. [CrossRef]

177. Garnett, T. Where are the best opportunities for reducing greenhouse gas emissions in the food system (including the food chain)? Food Policy 2011, 36, 23-32. [CrossRef]

178. Beauchemin, K.A.; McGinn, S.M.; Martinez, T.F.; McAllister, T.A. Use of condensed tannin extract from quebracho trees to reduce methane emissions from cattle. J. Anim. Sci. 2007, 85, 1990-1996. [CrossRef]

179. Field, C.B.; Barros, V.; Stocker, T.F.; Dahe, Q.; Jon Dokken, D.; Ebi, K.L.; Mastrandrea, M.D.; Mach, K.J.; Plattner, G.K.; Allen, S.K.; et al. Managing the Risks of Extreme Events and Disasters to Advance Climate Change Adaptation: Special Report of the Intergovernmental Panel on Climate Change; Cambridge University Press: Cambridge, UK, 2012. [CrossRef]

(C) 2019 by the authors. Licensee MDPI, Basel, Switzerland. This article is an open access article distributed under the terms and conditions of the Creative Commons Attribution (CC BY) license (http://creativecommons.org/licenses/by/4.0/). 